\title{
Incentives, Information, and Organizational Form ${ }^{1}$
}

\author{
Eric Maskin \\ Department of Economics \\ Harvard University \\ Yingyi Qian \\ Department of Economics \\ Stanford University \\ and \\ Chenggang $\mathrm{Xu}$ \\ Department of Economics \\ London School of Economics
}

Revised: December, 1997

\begin{abstract}
$\underline{\text { Abstract }}$
We model an organization as a network of managers erected on top of a technology (here consisting of a collection of plants). In our framework, the role of a manager is to react to shocks that affect the plants he oversees by choosing an appropriate allocation of tasks for the managers under him. We argue that different organizational forms give rise to different information about managers' performance and therefore differ according to how effective incentives can be in encouraging good performance. In particular, we show that, under certain assumptions, the M-form (multi-divisional form) is likely to provide better incentives than the U-form (unitary form) because it promotes yardstick competition (i.e., relative performance evaluation) more effectively. We conclude by presenting evidence that the assumptions on which this comparison rests are satisfied for Chinese data.
\end{abstract}

Key Words: Organizational Form, Incentives, Information, Yardstick Competition, China

\footnotetext{
${ }^{1}$ We are grateful to Takeshi Amemiya, Masahiko Aoki, Patrick Bolton, Gary Chamberlain, Javier Hidalgo, Bengt Holmstrom, Jan Magnus, and Frank Wolak for helpful discussions, and to two referees and participants in seminars and conferences in Gerzensee, California Institute of Technology, Harvard, MIT, LSE, CEPR (Brussels), and the Chinese Academy of Social Sciences (Beijing) for useful comments. We thank Juzhong Zhuang for his help with the data; Nancy Hearst for her help with the literature; Angela Lee and Ying Qian for their research assistance. Maskin's research is supported by the NSF, Qian's research by a McNamara Fellowship at Stanford, and Xu's research by STICERD and CEP at LSE (CEP is sponsored by the ESRC).
} 


\title{
Incentives, Information, and Organizational Form
}

\author{
Eric Maskin, Yingyi Qian, and Chenggang Xu
}

\section{Introduction}

A central theoretical question is how organization makes a difference to economic performance. Obviously, technology will have a great bearing on the way a firm or economy performs. But, by an organization we mean the network of managers built on top of technology, e.g., the way a corporation is subdivided into different divisions, and the way a planned economy (such as China or the former Soviet Union) is divided into different functional or regional governing bodies. In this paper we argue that organizational form matters because it affects the quality of incentive schemes that can be given to managers.

Of course, in reality, the choice of productive technique and that of organizational structure may not be altogether independent decisions: to some extent, the former may dictate the latter and vice versa. But to focus on the effect of organization, we abstract from this interaction and assume that technology, modeled as a collection of plants, is fixed. In this way, we can explore the implications of alternative organizational forms erected on top of these plants.

In our framework, an organization is a network of managers who oversees other managers, and ultimately, as we move down the hierarchy, a set of plants. Different organizational forms give rise to different information about managers' performance. Therefore, we argue, they differ according to how effective incentives can be in encouraging good performance.

We focus on the comparison between two organizational forms: the M-form (multi-divisional form) and the U-form (unitary form). Both structures have figured prominently in corporate history (see Chandler, 1962; Williamson, 1975). A classic example of the U-form was the Ford Motor Company before the Second World War. In those days, Ford was organized into a number of functionally specialized departments: production, sales, purchasing, and so on. In other words, the various departments carried out complementary tasks; none was independent of the others. By contrast, General Motors under Alfred Sloan became the prototypical M-form; GM comprised (and still comprises) a collection of fairly self-contained divisions, e.g., 
Chevrolet, Pontiac, and Oldsmobile.

The terms 'M-form' and 'U-form' have been applied primarily to corporations. Recently, however, they have been brought into the study of comparative economic systems. In particular, Qian and Xu (1993) observed that an important difference between the economies of the former Soviet Union and China lies in their respective organizational structures. The Soviet economy was, in effect, a gigantic U-form; it consisted of approximately sixty specialized ministries, e.g., steel or mining. ${ }^{2}$ Since 1958 , however, the Chinese economy has more closely resembled an 'M-form;' it comprises a large number of reasonably self-sufficient regions (e.g., provinces, prefectures, etc.).

The potential benefits from the U-form -- mainly exploitation of scale economies -- have been discussed at length in the literature on the Soviet economy (e.g., Kornai, 1992). What are the countervailing advantages of the M-form? We argue that one such benefit may be better incentives, deriving from the familiar principle of yardstick competition (see, for example, Lazear and Rosen, 1981, Holmstrom, 1982, Nalebuff and Stiglitz, 1983, and Shleifer 1985). Indeed, relative performance evaluation appears to be widespread in China: provinces, cities, counties, townships, and villages are continually ranked by their performance in growth, output, foreign investment, etc. ${ }^{3}$ Interestingly, there did not appear to be such competition between the specialized ministries of the Soviet Union. The question is, why not? After all, in theory, we could compare the steel minister's performance with that of the mining minister. Admittedly, this seems intuitively more difficult than comparing regions that produce more-or-less the same array of goods. But on what is this intuition founded?

One answer could be that the 'variation' between the performances of two regions producing similar

\footnotetext{
${ }^{2}$ The current Russian economy, including privatized firms, is still deeply affected by its U-form legacy. Data from field work show that Russian firms are still strongly influenced by industrial ministries (Earle and Ross, 1996).

${ }^{3}$ The Chinese central government has pursued an explicit policy during reform to stimulate regional competition, such as encouraging regions to "get rich first." Indeed, relative performance criteria are sometimes formally incorporated in the procedures for determining government officials' promotions and bonuses. For example, some county governments use the annual ranking of townships (by profit rate on total capital) as a primary criterion to evaluate township government officials (Chapter 2, Whiting, 1995). Moreover, government statistical reports and the mass media regularly publish rankings of regions in terms of their performances in growth, profit, foreign investment, etc. Most authoritative national or regional statistical books publish national or regional rankings of provinces, cities and/or counties every year.
} 
outputs is likely to be lower (in the appropriate statistical sense) than that between the performances of two production ministries. If this is so, yardstick competition between two regions will be more effective in providing incentives than that between two ministries, and thus an M-form will dominate from the standpoint of providing managerial incentives. Of course, this comes down in the end to a matter of empirics. But here our analysis of data from 520 Chinese state-owned enterprises seems to support the hypothesis that it is "easier" to compare different regions than different industries. In any case, the more general lesson that we are trying to draw is that different organizational forms give rise to different information on which incentives can be based.

We proceed as follows. In section 2, we lay out the model and discuss why we focus on M-form and U-form organizations. In section 3, we present our theoretical results. Proposition 2 shows that the M-form provides better incentives for middle-level managers provided that there is "less variation" in interregional performance than in interindustry performance. The comparison is independent of utility functions of both the principal and agents. Proposition 1 establishes that it is only at the middle level that organizational form has any bearing on incentive issues: both top- and bottom-level managers' incentives turn out to be independent of whether the M-form or the U-form is employed.

Then, in section 4, we develop the test statistics needed to analyze our Chinese data set. Our empirical work is reported in section 5, where we argue that there is indeed higher "variation" in performance across industries than across regions. We also offer systematic evidence to show the use of yardstick competition in the Chinese economy. We make a few concluding remarks in section 6.

\section{The Model}

Consider an economy with two regions, A and B; two industries, 1 and 2; and four plants, one plant for each region-industry combination: $1 \mathrm{~A}, 1 \mathrm{~B}, 2 \mathrm{~A}$, and $2 \mathrm{~B}$, where plant ir produces industry i output $(\mathrm{i}=1,2)$ and is located in region $\mathrm{r}(\mathrm{r}=\mathrm{A}, \mathrm{B}) .{ }^{4}$ There are three kinds of shocks: shocks $\eta$ hit all plants in the economy;

\footnotetext{
${ }^{4}$ With this specification, we rule out the possibility that all plants from a given industry be located in the same region, although this was roughly the case for some industries in the Soviet economy. The reason for ruling it out is that it implies that organization by region is identical to organization by industry, whereas we are interested in the contrast between the two.
} 
shocks $\theta_{\mathrm{i}}$ hit just plants in industry $\mathrm{i}, \mathrm{i}=1,2$; shocks $\delta_{\mathrm{r}}$ hit region $\mathrm{r}, \mathrm{r}=\mathrm{A}, \mathrm{B}$. We assume that shocks are jointly normally distributed.

We suppose each shock is allocated to one or more managers, ${ }^{5}$ each of whom indirectly oversees the set of plants affected by that shock (these plants are said to be in the manager's span of control). For completeness, we also assume that there is a plant manager to directly oversee each plant, but plant managers' behavior will not be studied (in a more elaborate model, we could introduce idiosyncratic shocks to plants which would make plant managers more like their higher level counterparts, but for simplicity, we dispense with those here).

A manager allocated a given shock attempts to counteract the possible adverse effects of that shock by assigning tasks to his subordinates. For example, imagine that a regional governor detects a weather pattern that indicates there may be more rainfall than usual in the region. If left unattended, this rainfall could result in reduction of agricultural output and disruption of normal commercial transportation. The governor might therefore issue orders to the agricultural minister to favor those crops -- such as rice -- that thrive on water and to the transportation minister to reroute trains through the highlands. ${ }^{6}$

To avoid a subordinate being assigned conflicting tasks, we suppose that he has at most one "boss," i.e., he receives orders from at most one superior manager. This implies that some shocks will necessarily be assigned to more than one manager. For example, consider the manager of the plant in industry 1 in region A. Suppose that his immediate superior manages shock $\theta_{1}$, the industry- 1 shock. Then this $\theta_{1}$-manager must have a $\delta_{\mathrm{A}}$-manager as superior (since someone must manage the $\delta_{\mathrm{A}}$-shock hitting the plant in question). But the $\theta_{1}$-manager cannot have the industry-1 plant from region $\mathrm{B}$ (the 1B-plant) in his span of control; otherwise, this plant would also be in the span of control of his superior, the $\delta_{\mathrm{A}}$-manager,

\footnotetext{
${ }^{5}$ To reflect the idea that there are economies of scale from specialization, we suppose that it is not efficient to assign more than one sort of shock to the same manager. On the other hand, implicit in the assumption that each shock is assigned to some manager is the hypothesis that the shock is important enough to require "managing."

${ }^{6}$ There is another -- and perhaps more "standard" -- interpretation of our model. Instead of an entire economy, think of the organization as a corporation, say, an automobile manufacturer. The "regions" would then correspond to two different car models, whereas the two "industries" would become two different specialized departments, e.g., production and purchasing. Shocks to "regions" (models) could then be interpreted as shifts in demand for these models, whereas shocks to "industries" (departments) might reflect changes in the cost of labor or parts.
} 
which does not make sense. Hence, there must be at least one other $\theta_{1}$-manager to oversee the 1B-plant.

Given that some duplication of managerial effort is inevitable, we note that the two organizational forms that best economize on managers are the $\mathrm{U}$-form and the $\mathrm{M}$-form. That is, these are the two structures that minimize the total number of managers subject to the no-multiple-boss requirement and the constraint that every shock hitting a plant is allocated to at least one manager overseeing that plant.

If the economy is set up as a U-form, then it is organized along industrial (ministerial) lines. Beneath the top manager, who is allocated shock $\eta$, there is a manager (minister) for each of the two industries (ministries). Then within each industry, there are managers for the two regional shocks (and for the two plants). Hence, a U-form is illustrated by Figure 1.

\section{Figure 1. A U-form Organization}

manager allocated $\eta$

manager allocated $\theta_{1}$

manager allocated $\delta_{\mathrm{A}}$

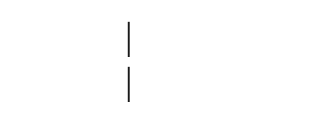

plant $1 \mathrm{~A}$ manager allocated $\delta_{\mathrm{B}}$

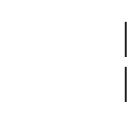

plant 1B manager allocated $\theta_{2}$

If the economy is configured as an M-form, then it is organized along regional lines. In this case there is again a top manager, who is allocated shock $\eta$. Then, at the next level down, there is a manager (governor) in charge of each of the two regions. Next, within a region, there is a manager for each of the industrial shocks. The M-form is depicted in Figure 2. 


\section{Figure 2. An M-form Organization}

\section{manager allocated $\eta$}

manager allocated $\delta_{\mathrm{A}}$

manager allocated $\theta_{1}$

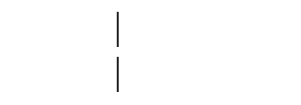

plant $1 \mathrm{~A}$ manager allocated $\theta_{2}$

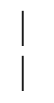

plant $2 \mathrm{~A}$ manager allocated $\delta_{\mathrm{B}}$

Consider a manager who is allocated shock $\delta_{\mathrm{r}}$. Suppose that in the absence of his taking any corrective action, the shock induces an expected decrease of $d$ in the output of each plant in his span of control. In the meteorological example above, $\mathrm{d}$ might correspond the average fall in agricultural output or increase in transportation delay if there were no shift in crop patterns or rerouting of trains. ${ }^{7}$ The manager can partly counteract the effect of the shock by assigning appropriate tasks to his subordinates. Let $e_{r}$ measure how well he works out this assignment (it corresponds to the manager's effort): expected output is raised by $\mathrm{e}_{\mathrm{r}}$ in all plants in his span of control.

Now, because absolute levels play no role in our analysis, we can take the value of $\mathrm{d}$, as well the means of all shocks, to be zero. Hence the output of a plant in industry $i$ and region $r$, when the managers

\footnotetext{
${ }^{7}$ We have been speaking of shocks as though they are necessarily a bad thing. But, in the case of a favorable shock, we can reinterpret $d$ as the maximum possible average increase in output that the shock permits. Thus, if the manager does nothing in response to the shock, average output is lower by d relative to what it would have been had the manager taken full advantage of the shock.
} 
allocated the shocks $\theta_{i}, \delta_{r}$, and $\eta$ hitting that plant exert efforts $e_{i}, e_{r}$, and $e_{\eta}$ respectively, is

$$
\mathrm{x}_{\mathrm{ir}}=\mathrm{e}_{\mathrm{i}}+\mathrm{e}_{\mathrm{r}}+\mathrm{e}_{\eta}+\theta_{\mathrm{i}}+\delta_{\mathrm{r}}+\eta \text {. }
$$

(There is no need to consider the plant manager's effort because in this simple model he is not allocated a shock; a plant manager's only role is to carry out the order of a superior.) The cost of effort e is C(e) where $\mathrm{C}(0)=0$, and

$$
\mathrm{dC} / \mathrm{de}>0 \text {, and } \mathrm{d}^{2} \mathrm{C} / \mathrm{de}^{2}>0
$$

A manager's utility is given by

$$
\mathrm{U}(\mathrm{t})-\mathrm{C}(\mathrm{e})
$$

where $t$ is the manager's (monetary) payment and $\mathrm{U}$ is his von Neumann-Morgenstern utility function. Let $\underline{\mathrm{U}}$ be the manager's reservation utility.

We will suppose that managers' efforts cannot be directly monitored. Hence, a manager's reward t will depend only on the observable outputs $\left\{\mathrm{x}_{\mathrm{ir}}\right\}$. The organizational problem is to choose a set $\mathrm{M}$ of managers and a set of reward schemes $t_{j}(\bullet)$ for each manager $\mathrm{j}$ so as to maximize the expected value of net output

$$
\sum_{\mathrm{i}} \sum_{\mathrm{r}} \mathrm{x}_{\mathrm{ir}}-\sum_{\mathrm{j} \in \mathrm{M}} \mathrm{t}_{\mathrm{j}}(\bullet)
$$

subject to the constraints that each manager get at least his reservation utility and that he choose an effort level $\mathrm{e}^{*}$ that maximizes his own net expected utility:

$$
\mathrm{E}[\mathrm{U}(\mathrm{t}(\bullet))-\mathrm{C}(\mathrm{e})]
$$

\section{$\underline{\text { 3. Information and Incentives }}$}

The central point of our paper is that different organizational forms give rise to different information on which incentives can be based. We are particularly interested in comparing managers' incentives in Mform and U-form organizations.

We will argue that if there is less "variation" (in the appropriate sense) in shocks across regions than across industries, the M-form dominates the $\mathrm{U}$-form from the standpoint of incentives. To get a feel for the issues involved, let us consider an even simpler framework than that of our model. Suppose that there are 
two industries, 1 and 2, and that output in industry $i$ is given by

$$
\mathrm{x}_{\mathrm{i}}=\mathrm{e}_{\mathrm{i}}+\epsilon_{\mathrm{i}},
$$

where $e_{i}$ is the effort of the manager in charge of shock $\epsilon_{i}$, and $\left(\epsilon_{1}, \epsilon_{2}\right)$ are jointly normally distributed. Let us compare this with the case of two regions, $\mathrm{A}$ and $\mathrm{B}$, where output in region $\mathrm{r}$ is given by

$$
\mathrm{x}_{\mathrm{r}}=\mathrm{e}_{\mathrm{r}}+\epsilon_{\mathrm{r}}
$$

$\mathrm{e}_{\mathrm{r}}$ is the effort of the manager in charge of shock $\epsilon_{\mathrm{r}}$, and $\left(\epsilon_{\mathrm{A}}, \epsilon_{\mathrm{B}}\right)$ are jointly normal. All managers have preferences given by

$$
\mathrm{U}(\mathrm{t})-\mathrm{C}(\mathrm{e})
$$

where $\mathrm{t}$ is a transfer that in the industrial case can depend on $\left(\mathrm{x}_{1}, \mathrm{x}_{2}\right)$, and in the regional case on $\left(\mathrm{x}_{\mathrm{A}}, \mathrm{x}_{\mathrm{B}}\right)$.

In which scenario can better incentives be provided? It turns out that a comparison of conditional variances is the key. If

$$
\operatorname{Var}\left(\epsilon_{\mathrm{A}} \mid \epsilon_{\mathrm{B}}\right)<\operatorname{Var}\left(\epsilon_{1} \mid \epsilon_{2}\right)
$$

then manager A can be given better incentives than manager $1 .^{8}$ Moreover, if both

$$
\min \left\{\operatorname{Var}\left(\epsilon_{\mathrm{A}} \mid \epsilon_{\mathrm{B}}\right), \operatorname{Var}\left(\epsilon_{\mathrm{B}} \mid \epsilon_{\mathrm{A}}\right)\right\}<\min \left\{\operatorname{Var}\left(\epsilon_{1} \mid \epsilon_{2}\right), \operatorname{Var}\left(\epsilon_{2} \mid \epsilon_{1}\right)\right\}
$$

and

$$
\max \left\{\operatorname{Var}\left(\epsilon_{\mathrm{A}} \mid \epsilon_{\mathrm{B}}\right), \operatorname{Var}\left(\epsilon_{\mathrm{B}} \mid \epsilon_{\mathrm{A}}\right)\right\}<\max \left\{\operatorname{Var}\left(\epsilon_{1} \mid \epsilon_{2}\right), \operatorname{Var}\left(\epsilon_{2} \mid \epsilon_{1}\right)\right\},
$$

then both managers $\mathrm{A}$ and $\mathrm{B}$ can be given better incentives than manager 1 and 2 .

The less noisy output is as a function of effort, the easier it is to provide a manager with the incentive to supply effort. Condition (1) says that the residual noise that remains in manager A's performance after it is compared with that of manager B is smaller than the residual noise that remains in manager 1's performance after it is compared with that of manager 2.

To see that if (1) holds, manager A can be provided with better incentives than manager 1, fix an effort level e' for manager 2 and assume that managers choose effort levels noncooperatively. Suppose that $\mathrm{t}_{1}(\bullet, \bullet)$ is an incentive scheme for manager 1 such that $\mathrm{t}_{1}\left(\mathrm{x}_{1}, \mathrm{x}_{2}\right)$ is his transfer conditional on outputs $\left(\mathrm{x}_{1}, \mathrm{x}_{2}\right)$. We will show that, if (1) holds, we can find a transfer scheme $t_{A}(\bullet, \bullet)$ as a function of $\left(x_{A}, x_{B}\right)$ such that, if

\footnotetext{
${ }^{8}$ Here, as in the remainder of the paper, we must impose an exogenous upper bound on penalties or else, as a referee pointed out, there would exist incentive schemes approximating the first-best arbitrarily closely (à la Mirrlees (1974)).
} 
manager B exerts effort $\mathrm{e}^{\prime}$, the scheme $\mathrm{t}_{\mathrm{A}}(\bullet, \bullet)$ is equivalent to $\mathrm{t}_{1}(\bullet, \bullet)$. To see this, note that $(1)$ is equivalent to

$$
\sigma_{\mathrm{A}}^{2}-\left(\sigma_{\mathrm{AB}}\right)^{2} / \sigma_{\mathrm{B}}^{2} \leq \sigma_{1}^{2}-\left(\sigma_{12}\right)^{2} / \sigma_{2}^{2},
$$

where $\sigma_{\mathrm{r}}^{2}=\operatorname{Var}\left(\epsilon_{\mathrm{r}}\right), \mathrm{r}=\mathrm{A}, \mathrm{B} ; \sigma_{\mathrm{AB}}=\operatorname{Cov}\left(\epsilon_{\mathrm{A}}, \epsilon_{\mathrm{B}}\right) ; \sigma_{\mathrm{i}}^{2}=\operatorname{Var}\left(\epsilon_{\mathrm{i}}\right), \mathrm{i}=1,2 ;$ and $\sigma_{12}=\operatorname{Cov}\left(\epsilon_{1}, \epsilon_{2}\right)$.

Choose scalars

$$
\begin{gathered}
\alpha=\sigma_{\mathrm{AB}} / \sigma_{\mathrm{B}}{ }^{2}-\sigma_{12} /\left(\sigma_{2}{ }^{2} \sigma_{\mathrm{B}}{ }^{2}\right)^{1 / 2}, \\
\beta=\left(\sigma_{2}{ }^{2} / \sigma_{\mathrm{B}}{ }^{2}\right)^{1 / 2}, \text { and } \\
\gamma=(1-\beta) \mathrm{e}^{\prime} .
\end{gathered}
$$

Also let $\mathrm{z}$ be a normally distributed random variable, independent of $\mathrm{x}_{\mathrm{A}}$ and $\mathrm{x}_{\mathrm{B}}$, with mean $\alpha \mathrm{e}^{\prime}$ and variance $\left[\operatorname{Var}\left(\epsilon_{1} \mid \epsilon_{2}\right)-\operatorname{Var}\left(\epsilon_{\mathrm{A}} \mid \epsilon_{\mathrm{B}}\right)\right]$. We claim that if managers 2 and B choose effort e', then for any choice of effort e by manager 1 and $A$, the two pairs of random variable $\left(x_{1}, x_{2}\right)$ and $\left(x_{A}-\alpha x_{B}+z, \beta x_{B}+\gamma\right)$ have the same distributions. Hence, if we take

$$
\mathrm{t}_{\mathrm{A}}\left(\mathrm{x}_{\mathrm{A}}, \mathrm{x}_{\mathrm{B}}\right)=\mathrm{t}_{1}\left(\mathrm{x}_{\mathrm{A}}-\alpha \mathrm{x}_{\mathrm{B}}+\mathrm{z}, \beta \mathrm{x}_{\mathrm{B}}+\gamma\right),
$$

$t_{A}(\bullet, \bullet)$ will be equivalent to $t_{1}(\bullet, \bullet)$. But because all random variables are normal, it suffices to show that the two pairs have the same mean and the same covariance matrix for all e. In fact:

$$
\begin{aligned}
& \mathrm{E}\left(\mathrm{x}_{\mathrm{A}}-\alpha \mathrm{x}_{\mathrm{B}}+\mathrm{z}\right)=\mathrm{e}-\alpha \mathrm{e}^{\prime}+\alpha \mathrm{e}^{\prime}=\mathrm{e}=\mathrm{Ex}_{1} ; \\
& \mathrm{E}\left(\beta \mathrm{x}_{\mathrm{B}}+\gamma\right)=\beta \mathrm{e}^{\prime}+(1-\beta) \mathrm{e}^{\prime}=\mathrm{e}^{\prime}=\mathrm{Ex}_{2} ; \\
& \operatorname{Var}\left(\beta \mathrm{x}_{\mathrm{B}}+\gamma\right)=\beta^{2} \operatorname{Var}\left(\mathrm{x}_{\mathrm{B}}\right)=\sigma_{2}^{2}=\operatorname{Var}\left(\mathrm{x}_{2}\right) ; \\
& \operatorname{Cov}\left(\mathrm{x}_{\mathrm{A}}-\alpha \mathrm{x}_{\mathrm{B}}+\mathrm{z}, \beta \mathrm{x}_{\mathrm{B}}+\gamma\right)=\beta \sigma_{\mathrm{AB}}^{2}-\alpha \beta \sigma_{\mathrm{B}}^{2}=\sigma_{12}^{2}=\operatorname{Cov}\left(\mathrm{x}_{1}, \mathrm{x}_{2}\right) ; \\
& \operatorname{Var}\left(\mathrm{x}_{\mathrm{A}}-\alpha \mathrm{x}_{\mathrm{B}}+\mathrm{z}\right)=\sigma_{\mathrm{A}}^{2}-2 \alpha \sigma_{\mathrm{AB}}+\alpha^{2}{\sigma_{\mathrm{B}}}^{2}+\left[\operatorname{Var}\left(\epsilon_{1} \mid \epsilon_{2}\right)-\operatorname{Var}\left(\epsilon_{\mathrm{A}} \mid \epsilon_{\mathrm{B}}\right)\right] \\
& \quad=\sigma_{\mathrm{A}}{ }^{2}-\sigma_{\mathrm{AB}}{ }^{2} / \sigma_{\mathrm{B}}^{2}+\sigma_{12}{ }^{2} / \sigma_{2}^{2}+\sigma_{1}^{2}-\sigma_{12}{ }^{2} / \sigma_{2}^{2}-\left(\sigma_{\mathrm{A}}^{2}-\sigma_{\mathrm{AB}}{ }^{2} / \sigma_{\mathrm{B}}^{2}\right)=\sigma_{1}{ }^{2}=\operatorname{Var}\left(\mathrm{x}_{1}\right),
\end{aligned}
$$

as claimed.

We have been taking e' as fixed for managers 2 and B. But if (2) and (3) hold, a similar argument shows that manager B can be induced to choose the same effort level as manager 2 .

So far we have been examining a setup that is simpler than the model that we are really interested in. Let us return, thereafter, to the model of section 2. As in the stripped-down framework, let us suppose that managers' effort cannot be directly monitored, so that their rewards can be based only on the vector of outputs

$$
\left(\mathrm{x}_{1 \mathrm{~A}}, \mathrm{x}_{2 \mathrm{~A}}, \mathrm{x}_{1 \mathrm{~B}}, \mathrm{x}_{2 \mathrm{~B}}\right) \text {. }
$$


Let us also continue to assume that managers choose their effort levels noncooperatively.

We have argued that, at least in the stripped-down model, the M-form provides better incentives than the U-form for middle-level managers (those one level down from top management), provided that conditional variances for regions are smaller than those for industries. It may appear at first that the comparison should go exactly the other way, once we move down to bottom-level managers. After all, the bottom-level managers are industrial in the M-form and regional in the U-form. Moreover, were the comparison to flip, we would get no clear-cut answer about the M-form versus the U-form. However, it turns out that the incentives for bottom-level managers do not depend on whether an M-form or U-form is employed (nor do they for top-level managers). Thus it suffices to consider only the incentives of middlelevel managers:

Proposition 1: Given any incentive scheme $t_{\eta}\left(x_{1 A}, x_{2 A}, x_{1 B}, x_{2 B}\right)$ for the top manager (the one handling $\eta$ ) in the $M$-form, there exists an equivalent scheme $t_{\eta}{ }^{\prime}\left(x_{1 A}, x_{2 A}, x_{1 B}, x_{2 B}\right)$ for the top manager in the U-form (in the sense that it induces the same effort level and gives the managers the same expected payoff), and vice versa. Similarly, given any incentive scheme $\mathrm{t}_{\mathrm{ir}}(\bullet)$ for the industry i manager under the region $\mathrm{r}$ manager in the Mform, there exists an equivalent scheme $t_{r i}$ for the region $r$ manager under the industry i manager in the $U$ form, and vice versa.

Proof: Suppose that the industry 1 manager in region A (manager 1A) in the M-form faces incentive scheme $t_{1 A}\left(x_{1 A}, x_{2 A}, x_{1 B}, x_{2 B}\right)$. Moreover, suppose that, given their incentive schemes, the other bottom-level managers are induced to choose levels $\mathrm{e}_{2 \mathrm{~A}}{ }^{*}, \mathrm{e}_{1 \mathrm{~B}} *, \mathrm{e}_{2 \mathrm{~B}} *$ (where $\mathrm{e}_{\mathrm{ir}} *$ is the effort level of manager ir), the middlelevel managers are induced to choose levels $\mathrm{e}_{\mathrm{A}}{ }^{*}$ and $\mathrm{e}_{\mathrm{B}}{ }^{*}$, and the top manager level $\mathrm{e}_{\eta}{ }^{*}$.

Now consider the U-form and suppose that the bottom-level managers other than A1 (the region A manager in industry 1) have incentive schemes that induce them to choose levels $\mathrm{e}_{\mathrm{A} 2}{ }^{* *}, \mathrm{e}_{\mathrm{B} 1}{ }^{* *}, \mathrm{e}_{\mathrm{B} 2}{ }^{* *}$, the middle-level managers $\mathrm{e}_{1}{ }^{* *}$ and $\mathrm{e}_{2}{ }^{* *}$, and the top-level manager $\mathrm{e}_{\eta}{ }^{* *}$. Endow manager A1 with transfer function $\mathrm{t}_{\mathrm{A} 1}{ }^{\prime}\left(\mathrm{x}_{1 \mathrm{~A}}, \mathrm{x}_{2 \mathrm{~A}}, \mathrm{x}_{1 \mathrm{~B}}, \mathrm{x}_{2 \mathrm{~B}}\right)=\mathrm{t}_{1 \mathrm{~A}}\left(\mathrm{x}_{1 \mathrm{~A}}+\mathrm{e}_{\mathrm{A}}^{*}+\mathrm{e}_{\eta} *-\mathrm{e}_{1}^{* *}-\mathrm{e}_{\eta} * *, \mathrm{x}_{2 \mathrm{~A}}+\mathrm{e}_{\mathrm{A}}^{*}+\mathrm{e}_{\eta} *-\mathrm{e}_{2} * *-\mathrm{e}_{\eta} * *+\mathrm{e}_{2 \mathrm{~A}} *-\mathrm{e}_{\mathrm{A} 2} * *\right.$, 


$$
\left.\mathrm{x}_{1 \mathrm{~B}}+\mathrm{e}_{\mathrm{B}} *+\mathrm{e}_{\eta} *-\mathrm{e}_{1} * *-\mathrm{e}_{\eta} * *+\mathrm{e}_{1 \mathrm{~B}} *-\mathrm{e}_{\mathrm{B} 1} * *, \mathrm{x}_{2 \mathrm{~B}}+\mathrm{e}_{\mathrm{B}} *+\mathrm{e}_{\eta} *-\mathrm{e}_{2} * *-\mathrm{e}_{\eta} * *+\mathrm{e}_{2 \mathrm{~B}} *-\mathrm{e}_{\mathrm{B} 2} * *\right) .
$$

It is then straightforward to verify that, for any effort choice e by managers $\mathrm{A} 1$ or $1 \mathrm{~A}$, the random variables $\mathrm{t}_{\mathrm{A} 1}{ }^{\prime}(\bullet, \bullet, \bullet, \bullet)$ and $\mathrm{t}_{1 \mathrm{~A}}(\bullet, \bullet, \bullet, \bullet)$ are the same. The argument for top managers is similar. Q.E.D.

Proposition 1 relies on a simple idea: the information available on which to base incentives is the same across organizational forms for both top- and bottom-level managers. However (as our stripped-down framework already suggests), the same is not true of middle-level managers. Indeed, a major theme of this paper is that an important respect in which organizational forms differ is precisely in the information that they give rise to.

In both the $\mathrm{M}$-form and $\mathrm{U}$-form, incentive schemes can depend on $\left(\mathrm{x}_{1 \mathrm{~A}}, \mathrm{x}_{2 \mathrm{~A}}, \mathrm{x}_{1 \mathrm{~B}}, \mathrm{x}_{2 \mathrm{~B}}\right)$. However, the way this set is partitioned into spheres of influence of the two middle-level managers differs. In the M-form, the region $\mathrm{A}$ and $\mathrm{B}$ managers affect $\left(\mathrm{x}_{1 \mathrm{~A}}, \mathrm{x}_{2 \mathrm{~A}}\right)$ and $\left(\mathrm{x}_{1 \mathrm{~B}}, \mathrm{x}_{2 \mathrm{~B}}\right)$ respectively, whereas in the $\mathrm{U}$-form, the industry 1 and 2 managers affect $\left(\mathrm{x}_{1 \mathrm{~A}}, \mathrm{x}_{1 \mathrm{~B}}\right)$ and $\left(\mathrm{x}_{2 \mathrm{~A}}, \mathrm{x}_{2 \mathrm{~B}}\right)$ respectively. In our stripped-down framework, the M-form dominated the U-form from the standpoint of incentives if the M-form's associated conditional variances were smaller than those of the U-form. Now, in the model of section 2, we must compare pairs of random variables, which may seem more complicated than the stripped-down analysis. But it turns out that the comparisons can be reduced to one dimension. Specifically, let $\lambda_{\mathrm{A}}$ solve

$$
\min _{\lambda} \operatorname{Var}\left(\lambda \epsilon_{1 \mathrm{~A}}+(1-\lambda) \epsilon_{2 \mathrm{~A}} \mid \epsilon_{1 \mathrm{~B}}, \epsilon_{2 \mathrm{~B}}\right),
$$

and let $\lambda_{1}$ solve

$$
\min _{\lambda} \operatorname{Var}\left(\lambda \epsilon_{1 \mathrm{~A}}+(1-\lambda) \epsilon_{1 \mathrm{~B}} \mid \epsilon_{2 \mathrm{~A}}, \epsilon_{2 \mathrm{~B}}\right) .
$$

Define $\lambda_{\mathrm{B}}$ and $\lambda_{2}$ analogously. Let

$$
\epsilon_{\mathrm{r}}=\lambda_{\mathrm{r}} \epsilon_{1 \mathrm{r}}+\left(1-\lambda_{\mathrm{r}}\right) \epsilon_{2 \mathrm{r}}
$$

for $\mathrm{r}=\mathrm{A}, \mathrm{B}$, and

$$
\epsilon_{\mathrm{i}}=\lambda_{\mathrm{i}} \epsilon_{\mathrm{iA}}+\left(1-\lambda_{\mathrm{i}}\right) \epsilon_{\mathrm{iB}} .
$$

for $i=1,2$. We establish that appropriately aggregated information is equivalent to disaggregated information for incentive purposes. Because the shock $\eta$ plays no role in the subsequent analysis, we henceforth ignore it. 
Lemma 1: If $\left(\mathrm{x}_{1 \mathrm{~A}}, \mathrm{x}_{1 \mathrm{~B}}, \mathrm{x}_{2 \mathrm{~A}}, \mathrm{x}_{2 \mathrm{~B}}\right)$ and $\left(\mathrm{x}_{1 \mathrm{~A}}{ }^{*}, \mathrm{x}_{2 \mathrm{~A}}{ }^{*}, \mathrm{x}_{1 \mathrm{~B}}{ }^{*}, \mathrm{x}_{2 \mathrm{~B}}{ }^{*}\right)$ are the outputs in the U-form and M-form respectively, we can express

and

$$
\begin{gathered}
\left(\mathrm{x}_{1 \mathrm{~A}}, \mathrm{x}_{1 \mathrm{~B}}, \mathrm{x}_{2 \mathrm{~A}}, \mathrm{x}_{2 \mathrm{~B}}\right)=\left(\mathrm{x}_{1}, \mathrm{x}_{1}, \mathrm{x}_{2}, \mathrm{x}_{2}\right)+\left(\mathrm{u}_{1}, \mathrm{u}_{2}, \mathrm{u}_{3}, \mathrm{u}_{4}\right) \\
\left(\mathrm{x}_{1 \mathrm{~A}}{ }^{*}, \mathrm{x}_{2 \mathrm{~A}}{ }^{*}, \mathrm{x}_{1 \mathrm{~B}}{ }^{*}, \mathrm{x}_{2 \mathrm{~B}}{ }^{*}\right) \\
=\left(\mathrm{x}_{\mathrm{A}}{ }^{*}, \mathrm{x}_{\mathrm{A}}{ }^{*}, \mathrm{x}_{\mathrm{B}}{ }^{*}, \mathrm{x}_{\mathrm{B}}{ }^{*}\right)+\left(\mathrm{v}_{1}, \mathrm{v}_{2}, \mathrm{v}_{3}, \mathrm{v}_{4}\right),
\end{gathered}
$$

where $\left(\mathrm{x}_{1}, \mathrm{x}_{1}, \mathrm{x}_{2}, \mathrm{x}_{2}\right)$ and $\left(\mathrm{u}_{1}, \mathrm{u}_{2}, \mathrm{u}_{3}, \mathrm{u}_{4}\right)$ are uncorrelated, $\left(\mathrm{x}_{\mathrm{A}}{ }^{*}, \mathrm{x}_{\mathrm{A}}{ }^{*}, \mathrm{x}_{\mathrm{B}}{ }^{*}, \mathrm{x}_{\mathrm{B}}{ }^{*}\right)$ and $\left(\mathrm{v}_{1}, \mathrm{v}_{2}, \mathrm{v}_{3}, \mathrm{v}_{4}\right)$ are uncorrelated.

\section{Proof: See Appendix.}

Lemma 1 can be understood from standard linear regression theory. Vector $\left(\mathrm{x}_{1}, \mathrm{x}_{1}, \mathrm{x}_{2}, \mathrm{x}_{2}\right)$ is the fitted regression vector under the "best linear unbiased estimation" procedure for $\left(\mathrm{x}_{1 \mathrm{~A}}, \mathrm{x}_{1 \mathrm{~B}}, \mathrm{x}_{2 \mathrm{~A}}, \mathrm{x}_{2 \mathrm{~B}}\right)$. Therefore, the residual vector $\left(\mathrm{u}_{1}, \mathrm{u}_{2}, \mathrm{u}_{3}, \mathrm{u}_{4}\right)$ is uncorrelated (as well as independent due to normality) to $\left(\mathrm{x}_{1}\right.$, $\left.\mathrm{x}_{1}, \mathrm{x}_{2}, \mathrm{x}_{2}\right)$. This decomposition of $\left(\mathrm{x}_{1 \mathrm{~A}}, \mathrm{x}_{1 \mathrm{~B}}, \mathrm{x}_{2 \mathrm{~A}}, \mathrm{x}_{2 \mathrm{~B}}\right)$ essentially makes $\left(\mathrm{x}_{1}, \mathrm{x}_{2}\right)$ a sufficient statistic for $\left(\mathrm{x}_{1 \mathrm{~A}}\right.$, $\left.\mathrm{x}_{1 \mathrm{~B}}, \mathrm{x}_{2 \mathrm{~A}}, \mathrm{x}_{2 \mathrm{~B}}\right)$ under the U-form, and therefore, $\left(\mathrm{x}_{1}, \mathrm{x}_{2}\right)$ becomes an appropriate aggregation from the point of view of providing incentives (Holmstrom, 1982).

With the help of Lemma 1, we can establish the following lemma, which is the counterpart to our analysis of the stripped-down framework:

Lemma 2: Let $\mathrm{t}_{1}\left(\mathrm{x}_{1 \mathrm{~A}}, \mathrm{x}_{1 \mathrm{~B}}, \mathrm{x}_{2 \mathrm{~A}}, \mathrm{x}_{2 \mathrm{~B}}\right)$ be any transfer scheme for manager 1 in the U-form. Fix the effort levels at $\mathrm{e}^{\prime}$ for all managers but manager $\mathrm{A}$ in the $\mathrm{M}$-form and manager 1 in the $\mathrm{U}$-form. There exists an equivalent transfer scheme for manager $\mathrm{A}$ in the $\mathrm{M}$-form, i.e., a scheme $\mathrm{t}_{\mathrm{A}}\left(\mathrm{x}_{1 \mathrm{~A}}{ }^{*}, \mathrm{x}_{2 \mathrm{~A}}{ }^{*}, \mathrm{x}_{1 \mathrm{~B}}{ }^{*}, \mathrm{x}_{2 \mathrm{~B}}{ }^{*}\right)$ such that for all transfer values $\tau$ and all effort levels e by manager A or manager 1 ,

$$
\operatorname{Prob}\left(\mathrm{t}_{\mathrm{A}}\left(\mathrm{x}_{1 \mathrm{~A}}{ }^{*}, \mathrm{x}_{2 \mathrm{~A}}{ }^{*}, \mathrm{x}_{1 \mathrm{~B}}{ }^{*}, \mathrm{x}_{2 \mathrm{~B}}{ }^{*}\right)=\tau \mid \mathrm{e}\right)=\operatorname{Prob}\left(\mathrm{t}_{1}\left(\mathrm{x}_{1 \mathrm{~A}}, \mathrm{x}_{1 \mathrm{~B}}, \mathrm{x}_{2 \mathrm{~A}}, \mathrm{x}_{2 \mathrm{~B}}\right)=\tau \mid \mathrm{e}\right),
$$

if and only if

$$
\operatorname{Var}\left(\epsilon_{\mathrm{A}} \mid \epsilon_{\mathrm{B}}\right) \leq \operatorname{Var}\left(\epsilon_{1} \mid \epsilon_{2}\right)
$$

Proof: See Appendix. 
Finally, because the labels "1", "2", "A", and "B" are arbitrary, applying Lemma 2, we can compare the M-form and U-form straightforwardly as follows:

Proposition 2: Incentives under the M-form are at least as good as those under the U-form (in the sense that any $\mathrm{U}$-form incentive scheme can be replicated by an M-form incentive scheme) provided that

$$
\begin{aligned}
& \max \left\{\operatorname{Var}\left(\epsilon_{\mathrm{A}} \mid \epsilon_{\mathrm{B}}\right), \operatorname{Var}\left(\epsilon_{\mathrm{B}} \mid \epsilon_{\mathrm{A}}\right)\right\} \\
& \leq \max \left\{\operatorname{Var}\left(\epsilon_{1} \mid \epsilon_{2}\right), \operatorname{Var}\left(\epsilon_{2} \mid \epsilon_{1}\right)\right\},
\end{aligned}
$$

and

$$
\begin{aligned}
& \min \left\{\operatorname{Var}\left(\epsilon_{\mathrm{A}} \mid \epsilon_{\mathrm{B}}\right), \operatorname{Var}\left(\epsilon_{\mathrm{B}} \mid \epsilon_{\mathrm{A}}\right)\right\} \\
& \leq \min \left\{\operatorname{Var}\left(\epsilon_{1} \mid \epsilon_{2}\right), \operatorname{Var}\left(\epsilon_{2} \mid \epsilon_{1}\right)\right\},
\end{aligned}
$$

where $\epsilon_{\mathrm{B}}, \epsilon_{\mathrm{A}}, \epsilon_{1}$, and $\epsilon_{2}$ are given by (6) and (7).

Proposition 2 implies an incomplete ranking of the M-form and U-form in terms of managerial incentives. If both (8) and (9) hold, the M-form is at least as good as the U-form; if both fail, the U-form is at least as good as the M-form; and one of them is satisfied and another fails, the result is inclusive.

Notice that our method of argument is to compare two probability distributions of output signals under the alternative organizational forms. The managerial incentive schemes are entirely based on these probability distributions, regardless of particular form of the utility functions of managers. Therefore, our comparison of organizational forms is independent of the utility functions of the managers. Furthermore, it is also independent of the solution concept of the (non-cooperative) game played by the managers, such as Nash or dominant strategy equilibrium, or others.

When there is symmetry across regions and across industries and no correlation between industrial and regional shocks, the formulas of Proposition 2 can be simplified into the following intuitive conditions:

Corollary: Assume $\operatorname{Var}\left(\delta_{\mathrm{A}}\right)=\operatorname{Var}\left(\delta_{\mathrm{B}}\right)=\mathrm{V}_{\mathrm{R}}^{2}, \operatorname{Var}\left(\theta_{1}\right)=\operatorname{Var}\left(\theta_{2}\right)=\mathrm{V}_{\mathrm{I}}^{2}, \operatorname{Cov}\left(\theta_{\mathrm{i}}, \delta_{\mathrm{r}}\right)=0$ for $\mathrm{i}=1,2$ and $\mathrm{r}=\mathrm{A}, \mathrm{B}$. Let $\mathrm{V}_{12}=\operatorname{Cov}\left(\theta_{1}, \theta_{2}\right)$ and $\mathrm{V}_{\mathrm{AB}}=\operatorname{Cov}\left(\delta_{\mathrm{A}}, \delta_{\mathrm{B}}\right)$. Then, incentives under the M-form are at least as good as those under the U-form if and only if 


$$
\mathrm{V}_{\mathrm{R}}^{2}-\mathrm{V}_{\mathrm{AB}} \leq \mathrm{V}_{\mathrm{I}}^{2}-\mathrm{V}_{12}
$$

The corollary demonstrates a linear tradeoff between variances and covariances for the purpose of incentives.

\section{Test Statistics}

We wish to test the inequalities in Proposition 2 using Chinese data. To do so, we need to derive the test statistics for the conditional variances under the M-form and $\mathrm{U}$-form organizations. That is, we want to test hypothesis:

$$
\operatorname{Var}\left(\epsilon_{\mathrm{A}} \mid \epsilon_{\mathrm{B}}\right) \leq \operatorname{Var}\left(\epsilon_{1} \mid \epsilon_{2}\right) \text { and } \operatorname{Var}\left(\epsilon_{\mathrm{B}} \mid \epsilon_{\mathrm{A}}\right) \leq \operatorname{Var}\left(\epsilon_{2} \mid \epsilon_{1}\right)
$$

where $\epsilon_{\mathrm{A}}, \epsilon_{\mathrm{B}}, \epsilon_{1}$, and $\epsilon_{2}$ are defined by (6) and (7). Write $\epsilon=\left(\epsilon_{1}, \epsilon_{2}, \epsilon_{\mathrm{A}}, \epsilon_{\mathrm{B}}\right)^{\prime}$.

Suppose we have sample industry-specific and region-specific shocks

$$
\xi_{\mathrm{t}}^{\prime}=\left(\theta_{1 \mathrm{t}}, \theta_{2 \mathrm{t}}, \delta_{\mathrm{At}}, \delta_{\mathrm{Bt}}\right)
$$

$\mathrm{t}=1, \ldots, \mathrm{T}$, which is drawn from a population $\mathrm{N}(0, \Sigma)$. Let sample mean and sample covariance be, respectively,

$$
\hat{\xi}_{\mathrm{T}}=(1 / \mathrm{T}) \Sigma_{\mathrm{t}=1}^{\mathrm{T}} \xi_{\mathrm{t}}
$$

and

$$
\hat{\Sigma}=(1 / T) \Sigma_{t=1}^{T}\left(\xi_{t}-\hat{\xi}_{T}\right)\left(\xi_{t}-\hat{\xi}_{T}\right)^{\prime}
$$

It is easy to show that we can express $\epsilon=\Phi(\Sigma) \xi \sim \mathrm{N}(0, \Omega)$, where $\Phi(\Sigma)$ is a $4 \mathrm{x} 4$ matrix. Let

$$
\Omega=\left\{\begin{array}{l}
\omega_{11}, \omega_{12}, \omega_{1 \mathrm{~A}}, \omega_{1 \mathrm{~B}} \\
\omega_{21}, \omega_{22}, \omega_{2 \mathrm{~A}}, \omega_{2 \mathrm{~B}} \\
\omega_{\mathrm{A} 1}, \omega_{\mathrm{A} 2}, \omega_{\mathrm{AA}}, \omega_{\mathrm{AB}} \\
\omega_{\mathrm{B} 1}, \omega_{\mathrm{B} 2}, \omega_{\mathrm{BA}}, \omega_{\mathrm{BB}}
\end{array}\right]=\Phi(\Sigma) \Sigma \Phi(\Sigma)^{\prime} .
$$

Then we have 


$$
\begin{gathered}
\mathrm{V}\left(\epsilon_{\mathrm{A}} \mid \epsilon_{\mathrm{B}}\right)-\mathrm{V}\left(\epsilon_{1} \mid \epsilon_{2}\right)=\left[\omega_{\mathrm{AA}}-\omega_{\mathrm{AB}} \omega_{\mathrm{BB}}{ }^{-1} \omega_{\mathrm{BA}}\right]-\left[\omega_{11}-\omega_{12} \omega_{22}{ }^{-1} \omega_{21}\right], \text { and } \\
\mathrm{V}\left(\epsilon_{\mathrm{B}} \mid \epsilon_{\mathrm{A}}\right)-\mathrm{V}\left(\epsilon_{2} \mid \epsilon_{1}\right)=\left[\omega_{\mathrm{BB}}-\omega_{\mathrm{BA}} \omega_{\mathrm{AA}}{ }^{-1} \omega_{\mathrm{AB}}\right]-\left[\omega_{22}-\omega_{21} \omega_{11}{ }^{-1} \omega_{12}\right] .
\end{gathered}
$$

Therefore, if we define $\mathrm{h}_{1}(\Omega)=\mathrm{V}\left(\epsilon_{\mathrm{A}} \mid \epsilon_{\mathrm{B}}\right)-\mathrm{V}\left(\epsilon_{1} \mid \epsilon_{2}\right), \mathrm{h}_{2}(\Omega)=\mathrm{V}\left(\epsilon_{\mathrm{B}} \mid \epsilon_{\mathrm{A}}\right)-\mathrm{V}\left(\epsilon_{2} \mid \epsilon_{1}\right)$, and $\mathrm{h}(\Omega)^{\prime}=\left(\mathrm{h}_{1}(\Omega), \mathrm{h}_{2}(\Omega)\right)$, then testing (10) is the same as testing

$$
\mathrm{H}_{0}: \mathrm{h}(\Omega) \leq 0 \text { vs. } \mathrm{H}_{1}: \mathrm{h}(\Omega) \in \mathrm{R}^{2} .
$$

Wolak (1987) has studied asymptotic properties of a test statistic for multiple inequality constraints in the linear regression model like ours. Applying Wolak's result, we derive:

Proposition 3: There is a $2 \times 2$ symmetric positive definite matrix $\mathrm{D}(\Sigma)$ such that test statistic

$$
\mathrm{TS}_{\mathrm{h}}=\min \left\{\mathrm{T}(\mathrm{h}(\Omega(\hat{\Sigma}))-\mathrm{x})^{\prime} \mathrm{D}(\widehat{乏})^{-1}(\mathrm{~h}(\Omega(\hat{\Sigma}))-\mathrm{x}), \text { s.t. } \mathrm{x} \leq 0\right\}
$$

has the asymptotic distribution of a weighted sum of $\chi_{1}^{2}$ and $\chi_{2}^{2}$ distributions and the weights are (1/2) and $\mathrm{w}$ respectively, where $0 \leq \mathrm{w}=(1 / 2) \pi^{-1} \arccos \left(\rho_{12}\right) \leq 1 / 2$ and $\rho_{12}$ is the correlation coefficient associated with $\mathrm{D}(\Sigma)$

\section{Proof: See Appendix.}

Because of Proposition 3, we can define c such that

$$
(1 / 2) \operatorname{prob}\left(\chi_{1}^{2} \geq \mathrm{c}\right)+(\mathrm{w}) \operatorname{prob}\left(\chi_{2}^{2} \geq \mathrm{c}\right)=0.01 \alpha .
$$

Then if $\mathrm{TS}_{\mathrm{h}} \leq \mathrm{c}, \mathrm{H}_{0}$ is accepted; and if $\mathrm{TS}_{\mathrm{h}}>\mathrm{c}, \mathrm{H}_{0}$ is rejected (at $\alpha \%$ significance level).

However, solving (12) often involves complicated calculation for the weight $\mathrm{w}$, which in turn depends on matrix $\mathrm{D}(\Sigma)$. A much simpler method without using the weight $\mathrm{w}$ is to find lower bound $\mathrm{c}_{\ell}$ and upper bound $\mathrm{c}_{\mathrm{u}}$ which are solutions to (Wolak, 1987):

$$
(1 / 2) \operatorname{prob}\left(\chi_{1}^{2} \geq \mathrm{c}_{\ell}\right)=0.01 \alpha
$$

$$
(1 / 2) \operatorname{prob}\left(\chi_{1}^{2} \geq \mathrm{c}_{\mathrm{u}}\right)+(1 / 2) \operatorname{prob}\left(\chi_{2}^{2} \geq \mathrm{c}_{\mathrm{u}}\right)=0.01 \alpha \text {. }
$$


Obviously, $\mathrm{c}_{\ell}<\mathrm{c}<\mathrm{c}_{\mathrm{u}}$. Then we can easily calculate from the $\chi^{2}$ distribution table that $\mathrm{c}_{\ell}=1.64$ and $\mathrm{c}_{\mathrm{u}}=3.8$ at $10 \%$ significance level. If $\mathrm{TS}_{\mathrm{h}} \leq \mathrm{c}_{\ell}, \mathrm{H}_{0}$ is accepted; if $\mathrm{TS}_{\mathrm{h}} \geq \mathrm{c}_{\mathrm{u}}, \mathrm{H}_{0}$ is rejected; and if $\mathrm{c}_{\ell}<\mathrm{TS}_{\mathrm{h}}<\mathrm{c}_{\mathrm{u}}$, it is inconclusive; all at the $\alpha \%$ significance level. When it is inconclusive, an exact test with c solved from (12) has to be used.

\section{An Application to China}

\section{A. The M-form Economy of China}

Chandler (1966) and Williamson (1975) characterized the two predominant organizational forms of business corporations: the $\mathrm{U}$-form and the $\mathrm{M}$-form. The $\mathrm{U}$-form corporation has a unitary structure and is organized along functional lines. It was popular in the late 1800s and early 1900s. The M-form corporation, by contrast, consists of reasonably self-contained divisions and emerged in the 1920s. Recently, Qian and Xu (1993) proposed comparing the transition paths of economies in Eastern Europe and the former Soviet Union (EEFSU) with that of China from the standpoint of organizational structures. They observed that the economies of EEFSU resembled U-forms (also known as "branch organizations"), whereas the Chinese hierarchy has taken an M-form structure, in which divisions correspond to regions. ${ }^{9}$

It is well documented that enterprises in EEFSU were grouped by industry, each of which was supervised by a ministry (Gregory and Stuart, 1989). In order to fully exploit scale economies and avoid conflicting operations, there was little overlap of functions across ministries. Enterprises were highly specialized. Because of the strong interdependence between enterprises in different regions, comprehensive planning and administrative coordination between ministries at the top level of government were crucial for the normal operation of the economy.

China's planning system began by imitating the U-form Soviet model in its first five-year plan between 1953 and 1957, which was formulated with the help of the Soviets. However, China started to deviate from the Soviet scheme and moved toward an M-form economy in the late 1950s. In the process,

\footnotetext{
${ }^{9}$ Qian and Xu (1993) discussed the overall costs and benefits of U-forms and M-forms in terms of scale economies, incentives, and coordination, and also the implications of these costs and benefits for alternative approaches to reform.
} 
"blocks" (kuaikuai), i.e., regions, replaced "branches" (tiaotiao), i.e., specialized ministries, as the foundation of the planning system. In fact, there are now six regional levels for administration: central, provincial, prefecture, county, township and village (a municipality can have the rank of province, prefecture or county). Regions at the county level and above are relatively self-contained; indeed, they are nearly self-sufficient in function. Hence, the Chinese M-form is "deep" and differs from the U-form of the Soviet Union and Eastern Europe in a thorough-going way. ${ }^{10}$

\section{B. Evidence on Conditional Variances of Industrial and Regional Shocks}

We now investigate whether the conditional variance condition of Proposition 2 holds empirically. Implicitly, we are comparing the Chinese organizational form (M-form) with a hypothetical U-form. In this U-form, all firms would be organized into hypothetical industrial ministries (although some industrial ministries actually exist in China, most state-owned enterprises are under the control of regional governments). We will compare conditional variances of regional and industrial shocks under M-form and Uform arrangements.

Our data set consists of 520 Chinese state-owned enterprises from 1986 to $1991 .^{11}$ The enterprises sampled are drawn from more than thirty manufacturing industries, located in major cities of 20 different provinces. The data set contains industry classification codes and location codes for each enterprise.

In our regressions, we group the data by region and by industry so that a proper sample size is maintained. Moreover, as much as possible, we try to reflect actual organization. For industries, we group the data into units similar to Eastern European-style ministries, with headings such as "machinery," "chemicals," and "textiles." Indeed, because of data limitations, we concentrate on these three industries in particular, since they have the largest sample sizes. Because sample sizes in individual cities are too small, our regional exercises are carried out in two ways. In the first scheme, the cities are grouped into provinces.

\footnotetext{
${ }^{10}$ China's M-form economy is not mere decentralization at the national level due to its large size. Compare Hungary and Guangdong province. The former was organized in a U-form hierarchy with specialized ministries managing all firms, while the latter itself is also organized in an M-form with multiple regions consisting of prefectures, counties, townships and villages, all of them being self-contained economic units.

${ }^{11}$ The data were collected by the System Reform Research Institute in Beijing, China.
} 
We select the five provinces with the largest sample sizes. These are Liaoning, Hubei, Hunan, Jiangsu (which includes Shanghai), and Hebei (which includes Beijing and Tianjin). In the second scheme, we group cities into "large regions," where each region contains three to six neighboring provinces. We choose the four regions with the largest sample sizes. These are "East" (Jiangsu, Anhui, Zhejiang, and Shanghai), "North" (Hebei, Henan, Shandong, Shanxi, Beijing, Tianjin), "Northeast" (Heilongjiang, Jilin, Liaoning), and "Central South" (Hubei, Hunan, Guangdong, Guangxi, and Fujian), which comprise a total of 18 provinces.

We use the log-linear Cobb-Douglas production function as our regression model to estimate industry-specific shocks $(\theta)$ and region-specific shocks $(\delta)$. For every industry i, region $r$, and period t, we include dummy variables $\mathrm{D}_{\mathrm{it}}{ }^{\mathrm{I}}$ and $\mathrm{D}_{\mathrm{rt}}{ }^{\mathrm{R}}$. The coefficients of these dummies serve as proxies for the industryspecific and region-specific shocks in the given period. Formally, we have

$$
\begin{aligned}
& \mathrm{E}(\mathrm{y} \mathrm{L}, \mathrm{k}) \\
& =\left(\beta+\sum_{\mathrm{i}=1}{ }^{\mathrm{I}} \beta_{\mathrm{i}} \mathrm{D}_{\mathrm{i}}^{\mathrm{I}}\right) \mathrm{L}+\left(\gamma+\Sigma_{\mathrm{i}=1}{ }^{\mathrm{I}} \gamma_{\mathrm{i}} \mathrm{D}_{\mathrm{i}}^{\mathrm{I}}\right) \mathrm{K}+\Sigma_{\mathrm{t}=1}^{\mathrm{T}} \mathrm{D}_{\mathrm{t}} \eta_{\mathrm{t}}+\Sigma_{\mathrm{t}=1}^{\mathrm{T}} \Sigma_{\mathrm{r}=1}^{\mathrm{R}} \mathrm{D}_{\mathrm{rt}}{ }^{\mathrm{R}} \delta_{\mathrm{rt}}+\Sigma_{\mathrm{t}=1}{ }^{\mathrm{T}} \Sigma_{\mathrm{i}=1}{ }^{\mathrm{I}} \mathrm{D}_{\mathrm{it}}^{\mathrm{I}} \theta_{\mathrm{it}} \\
& =\left(\beta+\Sigma_{\mathrm{i}=1}^{\mathrm{I}} \beta_{\mathrm{i}} \mathrm{D}_{\mathrm{i}}^{\mathrm{I}}\right) \mathrm{L}+\left(\gamma+\Sigma_{\mathrm{i}=1}^{\mathrm{I}} \gamma_{\mathrm{i}} \mathrm{D}_{\mathrm{i}}^{\mathrm{I}}\right) \mathrm{K}+\Sigma_{\mathrm{t}=1}^{\mathrm{T}} \mathrm{D}_{\mathrm{t}} \eta_{\mathrm{t}} \\
& +\Sigma_{\mathrm{t}=1}^{\mathrm{T}}\left[\mathrm{D}_{\mathrm{Rt}}^{\mathrm{R}} \delta_{\mathrm{Rt}}+\Sigma_{\mathrm{r}=1}^{\mathrm{R}-1} \mathrm{D}_{\mathrm{rt}}^{\mathrm{R}} \delta_{\mathrm{rt}}\right]+\Sigma_{\mathrm{t}=1}^{\mathrm{T}}\left[\mathrm{D}_{\mathrm{It}}^{\mathrm{I}} \theta_{\mathrm{It}}+\Sigma_{\mathrm{i}=1}^{\mathrm{I}-1} \mathrm{D}_{\mathrm{it}}^{\mathrm{I}} \theta_{\mathrm{it}}\right] \\
& =\left(\beta+\sum_{\mathrm{i}=1}{ }^{\mathrm{I}} \beta_{\mathrm{i}} \mathrm{D}_{\mathrm{i}}^{\mathrm{I}}\right) \mathrm{L}+\left(\gamma+\Sigma_{\mathrm{i}=1}^{\mathrm{I}} \gamma_{\mathrm{i}} \mathrm{D}_{\mathrm{i}}^{\mathrm{I}}\right) \mathrm{K}+\Sigma_{\mathrm{t}=1}^{\mathrm{T}} \mathrm{D}_{\mathrm{t}} \eta_{\mathrm{t}} \\
& +\Sigma_{\mathrm{t}=1}^{\mathrm{T}}\left\{\left(\mathrm{D}_{\mathrm{t}}^{\mathrm{T}}-\Sigma_{\mathrm{r}=1}^{\mathrm{R}-1} \mathrm{D}_{\mathrm{rt}}^{\mathrm{R}}\right) \delta_{\mathrm{Rt}}+\Sigma_{\mathrm{r}=1}^{\mathrm{R}-1} \mathrm{D}_{\mathrm{rt}}^{\mathrm{R}} \delta_{\mathrm{rt}}\right\}+\Sigma_{\mathrm{t}=1}^{\mathrm{T}}\left\{\left(\mathrm{D}_{\mathrm{t}}^{\mathrm{T}}-\Sigma_{\mathrm{i}=1}^{\mathrm{I}-1} \mathrm{D}_{\mathrm{it}}^{\mathrm{I}}\right) \theta_{\mathrm{It}}+\Sigma_{\mathrm{i}=1}^{\mathrm{I}-1} \mathrm{D}_{\mathrm{it}}^{\mathrm{I}} \theta_{\mathrm{it}}\right\} \\
& =\left(\beta+\sum_{\mathrm{i}=1}{ }^{\mathrm{I}} \beta_{\mathrm{i}} \mathrm{D}_{\mathrm{i}}^{\mathrm{I}}\right) \mathrm{L}+\left(\gamma+\Sigma_{\mathrm{i}=1}{ }^{\mathrm{I}} \gamma_{\mathrm{i}} \mathrm{D}_{\mathrm{i}}^{\mathrm{I}}\right) \mathrm{K}+\Sigma_{\mathrm{t}=1}{ }^{\mathrm{T}} \mathrm{D}_{\mathrm{t}}^{\mathrm{T}} \zeta_{\mathrm{t}}+\Sigma_{\mathrm{t}=1}{ }^{\mathrm{T}} \Sigma_{\mathrm{r}=1}{ }^{\mathrm{R}-1} \mathrm{D}_{\mathrm{rt}}{ }^{\mathrm{R}} \delta_{\mathrm{rt}}{ }^{\prime}+\Sigma_{\mathrm{t}=1}{ }^{\mathrm{T}} \Sigma_{\mathrm{i}=1}^{\mathrm{I}-1} \mathrm{D}_{\mathrm{it}}{ }^{\mathrm{I}} \theta_{\mathrm{it}}{ }^{\prime}
\end{aligned}
$$

where

$$
\begin{aligned}
& \zeta_{\mathrm{t}}=\eta_{\mathrm{t}}+\delta_{\mathrm{Rt}}+\theta_{\mathrm{It}}, \\
& \delta_{\mathrm{rt}}{ }^{\prime}=\delta_{\mathrm{rt}}-\delta_{\mathrm{Rt}}, \text { and } \\
& \theta_{\mathrm{it}}{ }^{\prime}=\theta_{\mathrm{it}}-\theta_{\mathrm{It}},
\end{aligned}
$$

for $\mathrm{t}=1, \ldots, \mathrm{T} ; \mathrm{r}=1,2, \ldots, \mathrm{R}-1 ;$ and $\mathrm{i}=1,2, \ldots, \mathrm{I}-1$.

Because of an identification problem, ${ }^{12}$ we cannot estimate $\left(\theta_{\mathrm{it}}, \delta_{\mathrm{rt}}\right)$ directly. Instead, we drop the

$$
\begin{aligned}
& { }^{12} \text { Dummy variables here have the following property: } \\
& \qquad \begin{array}{l}
\mathrm{D}_{\mathrm{t}}^{\mathrm{T}}=\Sigma_{\mathrm{r}=1}{ }^{\mathrm{R}} \mathrm{D}_{\mathrm{rt}}^{\mathrm{R}}=\Sigma_{\mathrm{i}=1}{ }^{\mathrm{I}} \mathrm{D}_{\mathrm{it}}^{\mathrm{I}}=1 \text { in period } \mathrm{t} \\
=0 \text {, otherwise, }
\end{array}
\end{aligned}
$$

that is, the sum of the regional dummies is the same as that of the industrial dummies, which creates a collinearity problem. 
dummy variables of one region and one industry, and estimate the coefficients of the dummy variables for the remaining regions and industries. This can be interpreted as using the shocks in one region and one industry as a benchmark to estimate relative industry-specific and relative region-specific shocks $\left(\theta_{\mathrm{it}}{ }^{\prime}, \delta_{\mathrm{rt}}{ }^{\prime}\right)$ as defined in (14) and (15) above.

For any three regions and three industries, $\mathrm{R}=\mathrm{I}=3$, and $\mathrm{T}=6$, we take region 3 (which is region $\mathrm{C}$ ) and industry 3 as benchmarks. From the regressions we obtain a time series $\left(\theta_{1 \mathrm{t}}{ }^{\prime}, \theta_{2 \mathrm{t}}{ }^{\prime}, \delta_{\mathrm{At}}{ }^{\prime}, \delta_{\mathrm{Bt}}{ }^{\prime}\right)$, which, for notational simplicity, we denote by $\xi_{\mathrm{t}}=\left(\theta_{1 \mathrm{t}}, \theta_{2 \mathrm{t}}, \delta_{\mathrm{At}}, \delta_{\mathrm{Bt}}\right)$. In the test, we treat these estimated shocks as if they were real shocks that are uncorrelated over time.

We test the hypothesis that the conditional variances under the M-form are no greater than those under the U-form. The results are reported in Table 1 where cities are grouped into provinces and in Table 2 where cities are grouped into "large regions." Columns (1)-(4) report estimated conditional variances of regional shocks and industrial shocks, and column (5) reports the estimated test statistic $\mathrm{TS}_{\mathrm{h}}$.

Of the 63 results in Table 1 , there are 44 cases in which $\mathrm{TS}_{\mathrm{h}}=0$, that is, the estimated means of both conditional variances under the M-form are smaller than their counterparts under the U-form. In these cases, our hypothesis cannot be rejected at any significance level. In the remaining 29 cases where $\mathrm{TS}_{\mathrm{h}}>0$, no value of $\mathrm{TS}_{\mathrm{h}}$ is larger than the lower bound $\mathrm{c}_{\ell}=1.64$ (at the $10 \%$ significance level). Thus, the hypothesis cannot be rejected at the $10 \%$ level. The results in Table 2 show that out of 36 possible pairs of comparisons, $\mathrm{TS}_{\mathrm{h}}=$ 0 in 25 pairs. In the remaining 11 pairs our test statistic $\mathrm{TS}_{\mathrm{h}}$ is positive, that is, at least one estimated mean conditional variance under the $\mathrm{M}$-form is greater than its counterpart under the U-form. At the $10 \%$ significance level, we have the lower bound $\mathrm{c}_{\ell}=1.64$ and the upper bound $\mathrm{c}_{\mathrm{u}}=3.8$. In 10 out of the 11 pairs $\mathrm{TS}_{\mathrm{h}}<1.64$, and only one pair $\left(\mathrm{TS}_{\mathrm{h}}=3.16\right)$ falls into the inconclusive interval $(1.64,3.8)$. Therefore, except for one case out of 36 , our hypothesis cannot be rejected at the $10 \%$ significance level. In view of Proposition 2, this test result suggests that, for the case of Chinese enterprises, the M-form provides better information than the $\mathrm{U}$-form for the purpose of relative performance evaluation.

\section{Evidence on Regional Yardstick Competition}

The findings of section 5B suggest that the M-form facilitates yardstick competition, but one may 
ask whether such relative performance evaluations are actually used in China. We now provide some evidence that they are.

We will demonstrate a connection between promotions of regional government officials and relative performance evaluation. The Chinese political system is still under one-party rule, and so the representation of a region in the Party Central Committee indicates the status and power of the region's government officials. Reflecting the increased importance of regions in government, regional representation in the Party's Congress and Central Committee as a whole has increased significantly over the reform period. For example, in the 14th Party Congress, more than $70 \%$ of delegates were from provinces, whereas only about $16 \%$ were from the central government and central Party organs (Saich, 1992).

We use a province's representation in the Party's Central Committee as a proxy for the promotion chances of officials in that province. We normalize the representation by the province's population so as to use the "per capita number of Central Committee members" as an index. This is the ratio between the number of Central Committee members from that region and the region's population. We measure economic performance of a province by its growth rate in "national income" (the rough equivalent of GDP).

Table 3 lists the ranking of provincial per capita number of Central Committee members in the 11th Party Congress in 1977 (prank77 $)$ and in the 13th Party Congress in 1987 (prank87 $)$ ), and the ranking of provincial economic performance in growth rate one year before the Party Congress, that is, in 1976 $\left(\operatorname{erank}_{\mathrm{r}}\right.$ ) and in $1986\left(\operatorname{erank86}_{\mathrm{r}}\right)$ respectively (data for Ningxia and Tibet are not available). The 11th Central Committee was formed before reform started, and at that time promotion criteria were mostly political. It could, therefore, be viewed as a benchmark. The 13th Central Committee was formed in 1987 when reform had been ongoing for almost a decade, and improving economic performance was officially stated as the central task of the Party. Table 3 shows that some provinces (e.g., Fujian, Jiangsu, Xinjiang, Zhejiang) improved their relative growth rankings, and their relative rankings of representation in the Central Committee also increased significantly. In contrast, the relative growth rankings of some provinces (e.g., Anhui, Guangxi, and Qinghai) deteriorated, and so did their rankings in representation in the Central 
Committee. ${ }^{13}$

To investigate the use of relative performance incentives, we focus on how the changes in the relative ranking of economic performance are related to changes in the relative ranking of per capita numbers of Central Committee members. A simple regression model using the data in Table 3 shows the following result (the standard error of the estimated coefficient is in parentheses):

$$
\text { PINDEX }_{\mathrm{r}}=-0.453+1.76 \text { EINDEX }_{\mathrm{r}}, \mathrm{R}^{2}=0.671 .
$$

where

$$
\text { EINDEX }_{\mathrm{r}}=10^{*}\left\{(1 / \text { erank86 })-\left(1 / \text { erank76 } 6_{\mathrm{r}}\right)+\left(1 / \text { erank86 }{ }_{\mathrm{r}}\right)^{2}\right\}
$$

and

$$
\operatorname{PINDEX}_{\mathrm{r}}=10^{*}\left\{\left(1 / \operatorname{prank}_{\mathrm{r}}\right)-\left(1 / \operatorname{prank}_{\mathrm{r}} 7_{\mathrm{r}}\right)+\left(1 / \operatorname{prank}_{\mathrm{r}} 7_{\mathrm{r}}\right)^{2}\right\} .
$$

For province $\mathrm{r}, \mathrm{EINDEX}_{\mathrm{r}}$ is the index that measures the change in rank in economic performance between 1976 and 1986, while PINDEX $_{\mathrm{r}}$ is the index that measures the change in rank in political position between 1977 and 1987. Note that we work with inverses. The third terms in EINDEX and PINDEX, (1/erank86 ${ }_{\mathrm{r}}^{2}$ \} and $\left.\left(1 / \text { prank87 }{ }_{\mathrm{r}}\right)^{2}\right\}$ respectively, are incorporated into the indices of change in order to capture the feature that staying at the top requires more effort -- and thus requires a greater reward -- than staying at the bottom. ${ }^{14}$

The significant positive correlation between the change of relative economic performance and the change of relative political position of a region suggests the use of regional yardstick competition.

\section{Concluding Remarks}

Our work is complementary to some other comparative studies of organizations. Arrow (1974)

\footnotetext{
${ }^{13}$ There are of course important political factors that also had influence on the selection of the Central Committee members. Before reform, provinces such as Hunan, Hubei, and Jiangxi provinces were over-represented in the Central Committee because these were the home provinces of many revolutionary leaders (e.g. Mao Zedong was from Hunan), and other provinces such as Beijing were under-represented because of the purge in the Cultural Revolution, which ended just before the 11th Party Congress. Furthermore, some provinces such as Xinjiang have always been overrepresented because of their political significance.

${ }^{14}$ We have run many more regressions with alternative data sets and have obtained qualitatively similar results. Those results are available upon request.
} 
argues, as we do, that the information structures to which organizations give rise constitute an important characteristic by which they should be compared. Cremer (1980) studies how activities should be optimally grouped into shops in a resource allocation problem. Aoki (1986) investigates how Japanese firms are organized differently from those in the U.S. and what implications these differences have for comparative performance. Holmstrom and Milgrom $(1991,1994)$ study how tasks should be allocated to firms and managers when managers may perform more than one task.

On the literature of the U-form vs. M-form, Williamson (1975) suggests that in a U-form organization, the CEO may be overloaded with daily operational decisions, and therefore cannot concentrate on strategic decisions. An M-form organization helps to mitigate the overload by decentralizing decisionmaking. Milgrom and Roberts (1992) emphasize the advantage of the M-form corporation in coordinating finance and investment decisions. Aghion and Tirole (1995) compare the M-form and U-form from the standpoint of encouraging managerial initiative. Qian, Roland and Xu (1997) focus on organizational coordination issues, which they model as the problem of getting attributes suitably matched. They compare the M-form and U-form's efficacy in coordinating changes such as reform and innovation.

In closing, let us note that one hotly debated issue of current interest is how the European Union -- in particular, the European Union central bank -- should be organized. One point of view favors organization according to specialization, another according to region. Our theory implies the following advice: regional organization is preferable if and only if the conditional variances associated with the shocks hitting regions are smaller than those associated with the bank's special tasks. 


\section{Table 1}

Testing Industrial and Regional Variance and Conditional Variance (by Province)

11111111111111111111111111111111111111111111

(1)

(2)

(3)

(4)

(5)

\begin{tabular}{|c|c|c|c|c|c|}
\hline & $\begin{array}{l}\mathrm{V}\left(\epsilon_{\mathrm{A}} \mid \epsilon_{\mathrm{B}}\right) \\
111111111111\end{array}$ & $\begin{array}{l}\mathrm{V}\left(\epsilon_{\mathrm{B}} \mid \epsilon_{\mathrm{A}}\right) \\
111111111111\end{array}$ & $\begin{array}{l}\mathrm{V}\left(\epsilon_{1} \mid \epsilon_{2}\right) \\
1\|\|\|\| \| 1\end{array}$ & $\mathrm{~V}\left(\epsilon_{2} \mid \epsilon_{1}\right)$ & $\mathrm{TS}_{\mathrm{h}}$ \\
\hline PR11 & 0.0008187 & 0.0007571 & 0.0030142 & 0.0024633 & 0 \\
\hline PR12 & 0.0009656 & 0.0013551 & 0.0028583 & 0.0100515 & 0 \\
\hline PR13 & 0.0009623 & 0.0021445 & 0.0040004 & 0.0016873 & 0.16069 \\
\hline PR14 & 0.0003254 & 0.0009305 & 0.0038165 & 0.0011762 & 0 \\
\hline PR15 & 0.0007978 & 0.0003191 & 0.0045005 & 0.0016317 & 0 \\
\hline R16 & 0.0015251 & 0.0019038 & 0.0028962 & 0.0022384 & 0 \\
\hline R17 & 0.0019566 & 0.0010847 & 0.0024202 & 0.0015482 & 0 \\
\hline R18 & 0.0006965 & 0.0005134 & 0.0019411 & 0.0011535 & 0 \\
\hline PR19 & 0.0036261 & 0.0010941 & 0.0027306 & 0.0027949 & 0.1239956 \\
\hline PR21 & 0.0035188 & 5737 & 0.0 & 0.0 & 196 \\
\hline PR22 & 0.0125974 & 0.0033652 & 0.0064482 & 0.0 & 1.1546736 \\
\hline PR23 & 0.0007243 & 0.0005763 & 0.00 & 396 & 0 \\
\hline PR24 & 0.00 & 7348 & 3718 & 624 & 0 \\
\hline PR25 & 0.0008053 & 0.0056084 & 0.0031696 & 1095 & 0.14 \\
\hline PR26 & 0.0011198 & 0.0012982 & 0.0280702 & 0.0043337 & 0 \\
\hline PR27 & 0.0035219 & 0.0014758 & 0.0014134 & 0.0045301 & 1.4297282 \\
\hline PR28 & 0.0032017 & 0.0036066 & 0.0022232 & 0.0039406 & 0.4174463 \\
\hline PR29 & 0.0009339 & 0.0006265 & 0.0059682 & 0.0121066 & 0 \\
\hline PR3 & 0.00 & 3189 & 0.0086372 & 456 & 0.5450603 \\
\hline PR32 & 0.0116553 & 0.00325 & 0.0114781 & 0.0047748 & 0 \\
\hline PR33 & 0.0003516 & 0.0002477 & 0.0032018 & 0.0012271 & 0 \\
\hline PR34 & 0.0022851 & 0.0012984 & 0.0096523 & 0.0044628 & 0 \\
\hline PR35 & 0.0014829 & 0.0069914 & 0.0063509 & 0.0042792 & 0.2695177 \\
\hline PR36 & 0.001434 & 0.0013309 & 0.0381816 & 0.0041133 & 0 \\
\hline PR37 & 0.0017801 & 0.0006927 & 0.0026892 & 0.0043122 & 0 \\
\hline PR38 & 0.00 & 0.0 & 0.0033635 & 625 & 176 \\
\hline & & 000138 & 00123 & 3788 & 0 \\
\hline
\end{tabular}

Notes: Each line of the Tables 1 and 2 corresponding to one set of results corresponding to a specific three regions and three industries with one of the them taken as a benchmark. All the 63 lines in Table 1 are divided into seven groups. The seven groups are the following: group 1: Jiangsu, Hebei, Liaoning; group 2: Jiangsu, Liaoning, Hubei; group 3: Jiangsu, Liaoning, Hunan; group 4: Hubei, Liaoning, Hunan; group 5: Hebei, Liaoning, Hubei; group 6: Hebei, Liaoning, Hunan; and group 7: Hubei, Jiangsu, Hunan. In Table 2, the 36 lines are divided into four groups: group 1: East, North, Northeast; group 2: East, North, Central South; group 3: Northeast, North, Central South; group 4: Northeast, East, Central South. Within each group, we have nine comparison results by rotating the benchmark region and the benchmark industry among the three regions and three industries within the group. 
Table 1 (continued)

Testing Industrial and Regional Variance and Conditional Variance (by Province)

\begin{tabular}{|c|c|c|c|c|c|}
\hline & (1) & (2) & (3) & (4) & (5) \\
\hline & $\begin{array}{l}\mathrm{V}\left(\epsilon_{\mathrm{A}} \mid \epsilon_{\mathrm{B}}\right) \\
\end{array}$ & $\begin{array}{l}\mathrm{V}\left(\epsilon_{\mathrm{B}} \mid \epsilon_{\mathrm{A}}\right) \\
\end{array}$ & $\mathrm{V}\left(\epsilon_{1} \mid \epsilon_{2}\right)$ & $\mathrm{V}\left(\epsilon_{2} \mid \epsilon_{1}\right)$ & $\mathrm{TS}_{\mathrm{h}}$ \\
\hline PR41 & 0.0022107 & 0.0042633 & 0.0063843 & 0.0044466 & 0 \\
\hline PR42 & 0.0045825 & 0.0036649 & 0.009163 & 0.0031834 & 0.0330869 \\
\hline PR43 & 0.0042087 & 0.0078392 & 0.0067047 & 0.0037866 & 1.283058 \\
\hline PR44 & 0.0026567 & 0.0021724 & 0.0101624 & 0.0078117 & 0 \\
\hline PR45 & 0.0048027 & 0.0033586 & 0.0066146 & 0.0599119 & 0 \\
\hline PR46 & 0.0052495 & 0.0025457 & 0.0174984 & 0.0066967 & 0 \\
\hline PR47 & 0.0028687 & 0.002188 & 0.0051838 & 0.0071966 & 0 \\
\hline PR48 & 0.0044801 & 0.0044515 & 0.0031598 & 0.0106808 & 0.2720435 \\
\hline PR49 & 0.0047402 & 0.003174 & 0.0051034 & 0.0113329 & 0 \\
\hline PR51 & 0.0019198 & 0.00453 & 0.0024876 & 0.0018453 & 0.8994377 \\
\hline PR52 & 0.002041 & 0.0014745 & 0.00241 & 0.0018914 & 0 \\
\hline PR53 & 0.0005682 & 0.0008727 & 0.0025407 & 0.0024924 & 0 \\
\hline PR54 & 0.0040096 & 0.001339 & 0.003392 & 0.0067175 & 0.0483989 \\
\hline PR55 & 0.0006512 & 0.0012565 & 0.0028805 & 0.0143283 & 0 \\
\hline PR56 & 0.0008774 & 0.001117 & 0.0029163 & 0.0067734 & 0 \\
\hline PR57 & 0.0019528 & 0.0024209 & 0.0020744 & 0.0072606 & 0 \\
\hline PR58 & 0.0011385 & 0.0013931 & 0.0018707 & 0.0102239 & 0 \\
\hline PR59 & 0.0006934 & 0.0008906 & 0.0039924 & 0.0069858 & 0 \\
\hline PR61 & 0.0021139 & 0.0058389 & 0.0051549 & 0.0041415 & 0.2965862 \\
\hline PR62 & 0.0038292 & 0.0020893 & 0.0047473 & 0.0045516 & 0 \\
\hline PR63 & 0.0011121 & 0.0016206 & 0.0049029 & 0.0046627 & 0 \\
\hline PR64 & 0.0021749 & 0.0014442 & 0.0044179 & 0.0027746 & 0 \\
\hline PR65 & 0.0018646 & 0.0028379 & 0.0040928 & 0.012857 & 0 \\
\hline PR66 & 0.001113 & 0.0010564 & 0.0062856 & 0.0031007 & 0 \\
\hline PR67 & 0.0030414 & 0.0009696 & 0.0041567 & 0.0027338 & 0 \\
\hline PR68 & 0.0022042 & 0.0028437 & 0.0041358 & 0.0069915 & 0 \\
\hline PR69 & 0.001927 & 0.0008932 & 0.0063637 & 0.002802 & 0 \\
\hline PR71 & 0.0024754 & 0.0050791 & 0.0102891 & 0.0083058 & 0 \\
\hline PR72 & 0.0033104 & 0.002966 & 0.0083431 & 0.0060816 & 0 \\
\hline PR73 & 0.0033779 & 0.0083795 & 0.0154754 & 0.0061027 & 0.2567824 \\
\hline PR74 & 0.002703 & 0.001844 & 0.0066952 & 0.0023344 & 0 \\
\hline PR75 & 0.0047986 & 0.003487 & 0.0113504 & 0.0428088 & 0 \\
\hline PR76 & 0.0041169 & 0.0020171 & 0.0082085 & 0.0022948 & 0 \\
\hline PR77 & 0.0055198 & 0.0018183 & 0.0048365 & 0.0022892 & 0.0508461 \\
\hline PR78 & 0.0043981 & 0.0047133 & 0.0047888 & 0.0067743 & 0 \\
\hline PR79 & 0.0058755 & 0.0018537 & 0.0043716 & 0.0023171 & 0.2324766 \\
\hline
\end{tabular}


$\underline{\text { Table } 2}$

Testing Industrial and Regional Variance and Conditional Variance (by Large Region)

\begin{tabular}{|c|c|c|c|c|c|}
\hline & (1) & (2) & (3) & (4) & (5) \\
\hline & $\begin{array}{l}\mathrm{V}\left(\epsilon_{\mathrm{A}} \mid \epsilon_{\mathrm{B}}\right) \\
1111111111111\end{array}$ & $\begin{array}{l}\mathrm{V}\left(\epsilon_{\mathrm{B}} \mid \epsilon_{\mathrm{A}}\right) \\
11111111111111\end{array}$ & $\begin{array}{l}\mathrm{V}\left(\epsilon_{1} \mid \epsilon_{2}\right) \\
\|\| 1\|\|\|\| \| 1\end{array}$ & $\mathrm{~V}\left(\epsilon_{2} \mid \epsilon_{1}\right)$ & $\mathrm{TS}_{\mathrm{h}}$ \\
\hline LR11 & 0.0009876 & 0.000717 & 0.0025903 & 0.0014356 & 0 \\
\hline LR12 & 0.0008853 & 0.0005627 & 0.0061475 & 0.0015846 & 0 \\
\hline LR13 & 0.0020441 & 0.0007281 & 0.0026581 & 0.0040902 & 0 \\
\hline LR14 & 0.0008268 & 0.0007193 & 0.0024435 & 0.0027816 & 0 \\
\hline LR15 & 0.0006873 & 0.0011279 & 0.0092834 & 0.0012659 & 0 \\
\hline LR16 & 0.0007685 & 0.0011829 & 0.0033395 & 0.0015871 & 0 \\
\hline LR17 & 0.0005151 & 0.0011678 & 0.0016032 & 0.0024889 & 0 \\
\hline LR18 & 0.0007956 & 0.000601 & 0.0014715 & 0.0018291 & 0 \\
\hline LR19 & 0.0008224 & 0.0015445 & 0.0018787 & 0.0012828 & 0.0485825 \\
\hline LR21 & 0.0005335 & 0.001472 & 0.000835 & 0.0095962 & 0 \\
\hline LR22 & 0.0016437 & 0.0005659 & 0.0014412 & 0.0060323 & 0.0622105 \\
\hline LR23 & 0.0012722 & 0.0007375 & 0.007627 & 0.0068863 & 0 \\
\hline LR24 & 0.0009478 & 0.0012606 & 0.003262 & 0.0062783 & 0 \\
\hline LR25 & 0.0004361 & 0.0003698 & 0.0005611 & 0.0006254 & 0 \\
\hline LR26 & 0.000618 & 0.0006669 & 0.0020611 & 0.0013201 & 0 \\
\hline LR27 & 0.0015519 & 0.0010175 & 0.0072856 & 0.0062593 & 0 \\
\hline LR28 & 0.0002648 & 0.0016529 & 0.0072931 & 0.000737 & 0.1577814 \\
\hline LR29 & 0.0002031 & 0.0021522 & 0.0058771 & 0.000439 & 0.0807599 \\
\hline LR31 & 0.0005775 & 0.0012875 & 0.001453 & 0.0040046 & 0 \\
\hline LR32 & 0.0017089 & 0.0005776 & 0.0013437 & 0.0021527 & 0.5853984 \\
\hline LR33 & 0.0011759 & 0.0008448 & 0.0035925 & 0.0021431 & 0 \\
\hline LR34 & 0.0007168 & 0.0007843 & 0.0016867 & 0.0047914 & 0 \\
\hline LR35 & 0.000916 & 0.0006686 & 0.0011856 & 0.0015126 & 0 \\
\hline LR36 & 0.0010723 & 0.0008347 & 0.0053094 & 0.0019045 & 0 \\
\hline LR37 & 0.0011079 & 0.000722 & 0.0025876 & 0.0029192 & 0 \\
\hline LR38 & 0.0007325 & 0.0034549 & 0.0022474 & 0.002 & 0.3518275 \\
\hline LR39 & 0.0007093 & 0.0028758 & 0.0023074 & 0.0017212 & 0.0907792 \\
\hline LR41 & 0.0010433 & 0.0040568 & 0.0016852 & 0.0015885 & 0.9165561 \\
\hline LR42 & 0.0050836 & 0.0011803 & 0.0015829 & 0.0036032 & 3.1585944 \\
\hline LR43 & 0.0008049 & 0.0006459 & 0.0027002 & 0.0015179 & 0 \\
\hline LR44 & 0.0012797 & 0.0016134 & 0.0015776 & 0.0027378 & 0 \\
\hline LR45 & 0.0005507 & 0.0011771 & 0.0016617 & 0.0014342 & 0 \\
\hline LR46 & 0.0004704 & 0.0009846 & 0.0167323 & 0.001396 & 0 \\
\hline LR47 & 0.0031506 & 0.0007645 & 0.0014811 & 0.0039824 & 0.6695789 \\
\hline LR48 & 0.0006126 & 0.001314 & 0.0022435 & 0.0013026 & 0.0003513 \\
\hline LR49 & 0.0010576 & 0.0007848 & 0.0040202 & 0.0029437 & 0 \\
\hline
\end{tabular}




\begin{tabular}{|c|c|c|c|c|}
\hline \multicolumn{5}{|c|}{$\underline{\text { Table } 3}$} \\
\hline & 1976 & 1977 & 1986 & 1987 \\
\hline Province & $\begin{array}{l}\text { Rank in } \\
\text { Economic } \\
\text { Growth }^{\mathrm{a}} \\
\text { (erank76) }\end{array}$ & $\begin{array}{l}\text { Rank in Party } \\
\text { Central } \\
\text { Committee } \\
\text { Membership } \\
\text { (prank77) } \\
\end{array}$ & $\begin{array}{l}\text { Rank in } \\
\text { Economic } \\
\text { Growth }^{\mathrm{a}} \\
\text { (erank86) }\end{array}$ & $\begin{array}{l}\text { Rank in Party } \\
\text { Central } \\
\text { Committee } \\
\text { Membership } \\
\text { (prank87) }\end{array}$ \\
\hline Anhui & 24 & 15 & 27 & 21 \\
\hline Beijing & 1 & 27 & 1 & 1 \\
\hline Fujian & 21 & 6 & 10 & 5 \\
\hline Gansu & 8 & 23 & 20 & 15 \\
\hline Guangdong & 12 & 21 & 12 & 9 \\
\hline Guangxi & 11 & 16 & 25 & 26 \\
\hline Guizhou & 27 & 24 & 24 & 22 \\
\hline Hebei & 18 & 10 & 21 & 11 \\
\hline Heilongjiang & 7 & 26 & 16 & 23 \\
\hline Henan & 20 & 20 & 17 & 25 \\
\hline Hubei & 22 & 5 & 14 & 17 \\
\hline Hunan & 19 & 2 & 23 & 19 \\
\hline Jiangsu & 16 & 12 & 7 & 4 \\
\hline Jiangxi & 25 & 1 & 26 & 24 \\
\hline Jilin & 14 & 22 & 18 & 10 \\
\hline Liaoning & 4 & 17 & 6 & 7 \\
\hline Inner Mongolia & 9 & 14 & 15 & 14 \\
\hline Qinghai & 3 & 9 & 5 & 27 \\
\hline Shaanxi & 6 & 7 & 8 & 20 \\
\hline Shandong & 10 & 13 & 11 & 6 \\
\hline Shanghai & 2 & 4 & 2 & 2 \\
\hline Shanxi & 23 & 3 & 19 & 13 \\
\hline Sichuan & 26 & 18 & 22 & 18 \\
\hline Tianjin & 5 & 11 & 4 & 12 \\
\hline Xinjiang & 13 & 8 & 9 & 3 \\
\hline Yunnan & 15 & 25 & 13 & 16 \\
\hline Zhejiang & 17 & 19 & 3 & 8 \\
\hline
\end{tabular}

Sources: (a) State Statistic Bureau, 1990; and (b) Bartke, 1990, p.374. 


\section{Appendix: Proofs of Propositions}

Proof of Lemma 1: We take

$$
\begin{gathered}
\xi=\left(\theta_{1}, \theta_{2}, \delta_{\mathrm{A}}, \delta_{\mathrm{B}}\right)^{\prime}, \Sigma=\operatorname{var}(\xi), \\
\epsilon_{\mathrm{u}}=\left(\epsilon_{1 \mathrm{~A}}, \epsilon_{1 \mathrm{~B}}, \epsilon_{2 \mathrm{~A}}, \epsilon_{2 \mathrm{~B}}\right)^{\prime}, \Sigma_{\mathrm{u}}=\operatorname{var}\left(\epsilon_{\mathrm{u}}\right), \\
\epsilon_{\mathrm{m}}=\left(\epsilon_{1 \mathrm{~A}}, \epsilon_{2 \mathrm{~A}}, \epsilon_{1 \mathrm{~B}}, \epsilon_{2 \mathrm{~B}}\right)^{\prime}, \Sigma_{\mathrm{m}}=\operatorname{var}\left(\epsilon_{\mathrm{m}}\right),
\end{gathered}
$$

where

$$
\begin{aligned}
& \left(\epsilon_{1 \mathrm{~A}}, \epsilon_{1 \mathrm{~B}}, \epsilon_{2 \mathrm{~A}}, \epsilon_{2 \mathrm{~B}}\right)^{\prime}=\mathrm{A}_{\mathrm{u}} \xi, \Sigma_{\mathrm{u}}=\mathrm{A}_{\mathrm{u}} \Sigma \mathrm{A}_{\mathrm{u}}^{\prime}, \\
& \left(\epsilon_{1 \mathrm{~A}}, \epsilon_{2 \mathrm{~A}}, \epsilon_{1 \mathrm{~B}}, \epsilon_{2 \mathrm{~B}}\right)^{\prime}=\mathrm{A}_{\mathrm{m}} \xi, \Sigma_{\mathrm{m}}=\mathrm{A}_{\mathrm{m}} \Sigma \mathrm{A}_{\mathrm{m}}^{\prime}
\end{aligned}
$$

and

$$
\left.A_{u}=\left(\begin{array}{llll}
1 & 0 & 1 & 0 \\
1 & 0 & 0 & 1 \\
0 & 1 & 1 & 0
\end{array}\right), \quad A_{m}=\left(\begin{array}{llll}
1 & 0 & 1 & 0 \\
0 & 1 & 0 & 1
\end{array}\right), \begin{array}{llll}
0 & 1 & 1 & 0
\end{array}\right)
$$

Note that both $\mathrm{A}_{\mathrm{u}}$ and $\mathrm{A}_{\mathrm{m}}$ are singular, and so are $\Sigma_{\mathrm{u}}$ and $\Sigma_{\mathrm{m}}$. However, one can verify that $\operatorname{Rank}\left(\mathrm{A}_{\mathrm{u}}\right)=\operatorname{Rank}\left(\mathrm{A}_{\mathrm{m}}\right)=3$, and $\mathrm{A}_{\mathrm{u}}{ }^{\prime} \mathrm{R}=0$ and $\mathrm{A}_{\mathrm{m}}{ }^{\prime} \mathrm{R}=0$ for $\mathrm{R}=(1,-1,-1,1)^{\prime}$.

We prove the case for the $\mathrm{U}$-form (the case for the M-form is similar). Let

$$
\begin{aligned}
& \left.\left(\mathrm{x}_{1}, \mathrm{x}_{2}\right)^{\prime}=\left(\mathrm{C}_{\mathrm{u}}^{\prime}\left(\mathrm{C}_{\mathrm{u} 1} \Sigma \mathrm{C}_{\mathrm{u} 1}\right)^{\prime}\right)^{-1} \mathrm{C}_{\mathrm{u}}\right)^{-1} \mathrm{C}_{\mathrm{u}}^{\prime}\left(\mathrm{C}_{\mathrm{u} 1} \Sigma \mathrm{C}_{\mathrm{u} 1}\right)^{-1} \mathrm{Q}_{\mathrm{u}}^{\prime}\left(\mathrm{x}_{1 \mathrm{~A}}, \mathrm{x}_{1 \mathrm{~B}}, \mathrm{x}_{2 \mathrm{~A}}, \mathrm{x}_{2 \mathrm{~B}}\right)^{\prime} \\
& \left(\mathrm{x}_{\mathrm{A}}{ }^{*}, \mathrm{x}_{\mathrm{B}}{ }^{*}\right)^{\prime}=\left(\mathrm{C}_{\mathrm{m}}\left(\mathrm{C}_{\mathrm{m} 1} \Sigma \mathrm{C}_{\mathrm{m} 1}\right)^{-1} \mathrm{C}_{\mathrm{m}}\right)^{-1} \mathrm{C}_{\mathrm{m}}\left(\mathrm{C}_{\mathrm{m} 1} \Sigma \mathrm{C}_{\mathrm{m} 1}\right)^{-1} \mathrm{Q}_{\mathrm{m}}{ }^{\prime}\left(\mathrm{x}_{1 \mathrm{~A}}{ }^{*}, \mathrm{x}_{2 \mathrm{~A}}{ }^{*}, \mathrm{x}_{1 \mathrm{~B}}{ }^{*}, \mathrm{x}_{2 \mathrm{~B}}{ }^{*}\right)^{\prime} \\
& \mathrm{C}_{\mathrm{u}}=\mathrm{Q}_{\mathrm{u}}{ }^{\prime} \mathrm{A}, \mathrm{C}_{\mathrm{u} 1}=\mathrm{Q}_{\mathrm{u}}{ }^{\prime} \mathrm{A}_{\mathrm{u}}, \mathrm{C}_{\mathrm{m}}=\mathrm{Q}_{\mathrm{m}}{ }^{\prime} \mathrm{A}, \mathrm{C}_{\mathrm{m} 1}=\mathrm{Q}_{\mathrm{m}}{ }^{\prime} \mathrm{A}_{\mathrm{m}} \text {, }
\end{aligned}
$$

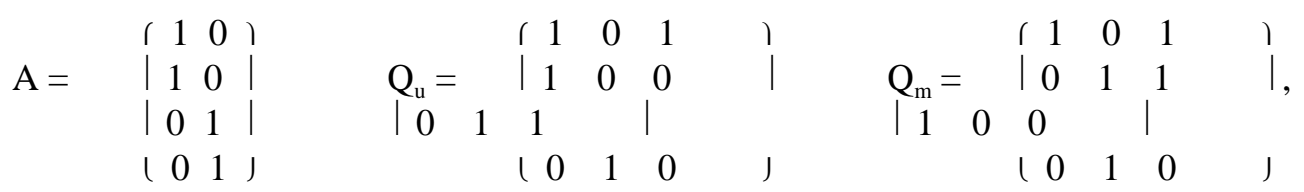

and $\left(\mathrm{C}_{\mathrm{u} 1} \Sigma \mathrm{C}_{\mathrm{u} 1}{ }^{\prime}\right)$ and $\left(\mathrm{C}_{\mathrm{m} 1} \Sigma \mathrm{C}_{\mathrm{m} 1}{ }^{\prime}\right)$ are non-singular $3 \times 3$ matrices.

Let $x=\left(x_{1 A}, x_{1 B}, x_{2 A}, x_{2 B}\right)^{\prime}$ and $\beta=\left(e_{1}, e_{2}\right)^{\prime}$. Then under the U-form:

$$
x=A \beta+A_{u} \xi .
$$


Let $\underline{x}=A\left(x_{1}, x_{2}\right)^{\prime}=\left(x_{1}, x_{1}, x_{2}, x_{2}\right)^{\prime}$ and $u=\left(u_{1}, u_{2}, u_{3}, u_{4}\right)=x-\underline{x}$. Because $E u=E x-E \underline{x}=A \beta-A \beta=0$, to show $\underline{x}$ and $u$ are uncorrelated, we need only show that Ex $u^{\prime}=0$. In fact,

Exu'

$=\operatorname{Ex}(\mathrm{x}-\underline{x})^{\prime}$

$=\mathrm{E}\left\{\mathrm{A}\left(\mathrm{C}_{\mathrm{u}}{ }^{\prime}\left(\mathrm{C}_{\mathrm{u} 1} \Sigma \mathrm{C}_{\mathrm{u} 1}\right)^{-1} \mathrm{C}_{\mathrm{u}}\right)^{-1} \mathrm{C}_{\mathrm{u}}{ }^{\prime}\left(\mathrm{C}_{\mathrm{u} 1} \Sigma \mathrm{C}_{\mathrm{u} 1}\right)^{-1} \mathrm{Q}_{\mathrm{u}}{ }^{\prime}\left(\mathrm{A} \beta+\mathrm{A}_{\mathrm{u}} \xi\right)\right\}$

$\left\{\left(\mathrm{I}-\mathrm{A}\left(\mathrm{C}_{\mathrm{u}}{ }^{\prime}\left(\mathrm{C}_{\mathrm{u} 1} \Sigma \mathrm{C}_{\mathrm{u} 1}\right)^{-1} \mathrm{C}_{\mathrm{u}}\right)^{-1} \mathrm{C}_{\mathrm{u}}{ }^{\prime}\left(\mathrm{C}_{\mathrm{u} 1} \Sigma \mathrm{C}_{\mathrm{u} 1}{ }^{\prime}\right)^{-1} \mathrm{Q}_{\mathrm{u}}{ }^{\prime}\right)\left(\mathrm{A} \beta+\mathrm{A}_{\mathrm{u}} \xi\right)\right\}^{\prime}$

$=\mathrm{E}\left\{\mathrm{A}\left(\mathrm{C}_{\mathrm{u}}{ }^{\prime}\left(\mathrm{C}_{\mathrm{u} 1} \Sigma \mathrm{C}_{\mathrm{u} 1}\right)^{-1} \mathrm{C}_{\mathrm{u}}\right)^{-1} \mathrm{C}_{\mathrm{u}}{ }^{\prime}\left(\mathrm{C}_{\mathrm{u} 1} \Sigma \mathrm{C}_{\mathrm{u} 1}\right)^{-1} \mathrm{Q}_{\mathrm{u}}{ }^{\prime}\left(\mathrm{A} \beta+\mathrm{A}_{\mathrm{u}} \xi\right)\right\}$

$\left(\mathrm{A}_{\mathrm{u}} \xi\right)^{\prime}\left\{\mathrm{I}-\mathrm{A}\left(\mathrm{C}_{\mathrm{u}}{ }^{\prime}\left(\mathrm{C}_{\mathrm{u} 1} \Sigma \mathrm{C}_{\mathrm{u} 1}{ }^{\prime}\right)^{-1} \mathrm{C}_{\mathrm{u}}\right)^{-1} \mathrm{C}_{\mathrm{u}}{ }^{\prime}\left(\mathrm{C}_{\mathrm{u} 1} \Sigma \mathrm{C}_{\mathrm{u} 1}{ }^{\prime}\right)^{-1} \mathrm{Q}_{\mathrm{u}}{ }^{\prime}\right\}^{\prime}$

$=\mathrm{E}\left\{\mathrm{A} \beta+\mathrm{A}\left(\mathrm{C}_{\mathrm{u}}^{\prime}\left(\mathrm{C}_{\mathrm{u} 1} \Sigma \mathrm{C}_{\mathrm{u} 1}\right)^{-1} \mathrm{C}_{\mathrm{u}}\right)^{-1} \mathrm{C}_{\mathrm{u}}{ }^{\prime}\left(\mathrm{C}_{\mathrm{u} 1} \Sigma \mathrm{C}_{\mathrm{u} 1}\right)^{-1} \mathrm{C}_{\mathrm{u} 1} \xi\right\}$

$$
\xi^{\prime} \mathrm{A}_{\mathrm{u}}^{\prime}\left\{\mathrm{I}^{-} \mathrm{Q}_{\mathrm{u}}^{\prime}\left(\mathrm{C}_{\mathrm{u} 1} \Sigma \mathrm{C}_{\mathrm{u} 1}\right)^{-1} \mathrm{C}_{\mathrm{u}}\left(\mathrm{C}_{\mathrm{u}}^{\prime}\left(\mathrm{C}_{\mathrm{u} 1} \Sigma \mathrm{C}_{\mathrm{u} 1}\right)^{-1} \mathrm{C}_{\mathrm{u}}\right)^{-1} \mathrm{~A}^{\prime}\right\}
$$

$=\mathrm{A}\left(\mathrm{C}_{\mathrm{u}}{ }^{\prime}\left(\mathrm{C}_{\mathrm{u} 1} \Sigma \mathrm{C}_{\mathrm{u} 1}\right)^{-1} \mathrm{C}_{\mathrm{u}}\right)^{-1} \mathrm{C}_{\mathrm{u}}^{\prime}\left(\mathrm{C}_{\mathrm{u} 1} \Sigma \mathrm{C}_{\mathrm{u} 1}\right)^{-1} \mathrm{C}_{\mathrm{u} 1} \mathrm{E}\left(\xi \xi^{\prime}\right) \mathrm{A}_{\mathrm{u}}{ }^{\prime}$

- $\mathrm{A}\left(\mathrm{C}_{\mathrm{u}}^{\prime}\left(\mathrm{C}_{\mathrm{u} 1} \Sigma \mathrm{C}_{\mathrm{u} 1}\right)^{-1} \mathrm{C}_{\mathrm{u}}\right)^{-1} \mathrm{C}_{\mathrm{u}}^{\prime}\left(\mathrm{C}_{\mathrm{u} 1} \Sigma \mathrm{C}_{\mathrm{u} 1}\right)^{-1} \mathrm{C}_{\mathrm{u} 1} \mathrm{E}\left(\xi \xi^{\prime}\right) \mathrm{C}_{\mathrm{u} 1}\left(\mathrm{C}_{\mathrm{u} 1} \Sigma \mathrm{C}_{\mathrm{u} 1}\right)^{-1} \mathrm{C}_{\mathrm{u}}\left(\mathrm{C}_{\mathrm{u}}^{\prime}\left(\mathrm{C}_{\mathrm{u} 1} \Sigma \mathrm{C}_{\mathrm{u} 1}\right)^{-1} \mathrm{C}_{\mathrm{u}}\right)^{-1} \mathrm{~A}^{\prime}$

$=\mathrm{A}\left(\mathrm{C}_{\mathrm{u}}{ }^{\prime}\left(\mathrm{C}_{\mathrm{u} 1} \Sigma \mathrm{C}_{\mathrm{u} 1}\right)^{-1} \mathrm{C}_{\mathrm{u}}\right)^{-1} \mathrm{C}_{\mathrm{u}}{ }^{\prime}\left(\mathrm{C}_{\mathrm{u} 1} \Sigma \mathrm{C}_{\mathrm{u} 1}\right)^{-1} \mathrm{C}_{\mathrm{u} 1} \Sigma \mathrm{A}_{\mathrm{u}}{ }^{\prime}-\mathrm{A}\left(\mathrm{C}_{\mathrm{u}}{ }^{\prime}\left(\mathrm{C}_{\mathrm{u} 1} \Sigma \mathrm{C}_{\mathrm{u} 1}{ }^{\prime}\right)^{-1} \mathrm{C}_{\mathrm{u}}\right)^{-1} \mathrm{~A}^{\prime}$

We multiply Exu' from the right a non-singular matrix $\left[Q_{u}, R\right]$, we have,

$\left[\mathrm{A}\left(\mathrm{C}_{\mathrm{u}}{ }^{\prime}\left(\mathrm{C}_{\mathrm{u} 1} \Sigma \mathrm{C}_{\mathrm{u} 1}\right)^{-1} \mathrm{C}_{\mathrm{u}}\right)^{-1} \mathrm{C}_{\mathrm{u}}{ }^{\prime}\left(\mathrm{C}_{\mathrm{u} 1} \Sigma \mathrm{C}_{\mathrm{u} 1}\right)^{-1} \mathrm{C}_{\mathrm{u} 1} \Sigma \mathrm{A}_{\mathrm{u}}{ }^{\prime}-\mathrm{A}\left(\mathrm{C}_{\mathrm{u}}{ }^{\prime}\left(\mathrm{C}_{\mathrm{u} 1} \Sigma \mathrm{C}_{\mathrm{u} 1}{ }^{\prime}\right)^{-1} \mathrm{C}_{\mathrm{u}}\right)^{-1} \mathrm{~A}^{\prime}\right] \mathrm{Q}_{\mathrm{u}}$

$=\mathrm{A}\left(\mathrm{C}_{\mathrm{u}}{ }^{\prime}\left(\mathrm{C}_{\mathrm{u} 1} \Sigma \mathrm{C}_{\mathrm{u} 1}\right)^{-1} \mathrm{C}_{\mathrm{u}}\right)^{-1} \mathrm{C}_{\mathrm{u}}{ }^{\prime}-\mathrm{A}\left(\mathrm{C}_{\mathrm{u}}{ }^{\prime}\left(\mathrm{C}_{\mathrm{u} 1} \Sigma \mathrm{C}_{\mathrm{u} 1}\right)^{-1} \mathrm{C}_{\mathrm{u}}\right)^{-1} \mathrm{C}_{\mathrm{u}}{ }^{\prime}$

$=0$.

We also have

$$
\left[\mathrm{A}\left(\mathrm{C}_{\mathrm{u}}{ }^{\prime}\left(\mathrm{C}_{\mathrm{u} 1} \Sigma \mathrm{C}_{\mathrm{u} 1}\right)^{-1} \mathrm{C}_{\mathrm{u}}\right)^{-1} \mathrm{C}_{\mathrm{u}}^{\prime}\left(\mathrm{C}_{\mathrm{u} 1} \Sigma \mathrm{C}_{\mathrm{u} 1}\right)^{-1} \mathrm{C}_{\mathrm{u} 1} \Sigma \mathrm{A}_{\mathrm{u}}{ }^{\prime}-\mathrm{A}\left(\mathrm{C}_{\mathrm{u}}{ }^{\prime}\left(\mathrm{C}_{\mathrm{u} 1} \Sigma \mathrm{C}_{\mathrm{u} 1}\right)^{-1} \mathrm{C}_{\mathrm{u}}\right)^{-1} \mathrm{~A}^{\prime}\right] \mathrm{R}=0
$$

because $\mathrm{A}_{\mathrm{u}}{ }^{\prime} \mathrm{R}=0$ and $\mathrm{A}^{\prime} \mathrm{R}=0$.

Therefore, E $\underline{x} u^{\prime}=0$, that is, $\underline{x}$ and $u$ are uncorrelated and $x=\underline{x}+u$.

Finally, one can show $\mathrm{x}_{1}$ and $\mathrm{x}_{\mathrm{A}}$ as defined above are just $\lambda_{1} \mathrm{x}_{1 \mathrm{~A}}+\left(1-\lambda_{1}\right) \mathrm{x}_{1 \mathrm{~B}}$ and

$\lambda_{\mathrm{A}} \mathrm{x}_{1 \mathrm{~A}}{ }^{*}+\left(1-\lambda_{\mathrm{A}}\right) \mathrm{x}_{2 \mathrm{~A}}{ }^{*}$, where $\lambda_{1}$ and $\lambda_{\mathrm{A}}$ are given by (4) and (5), respectively. Similarly for $\mathrm{x}_{2}$ and $\mathrm{x}_{\mathrm{B}}$. Q.E.D.

Proof of Lemma 2: $\quad$ Let

$$
\begin{aligned}
& \left(\epsilon_{1}, \epsilon_{2}\right)^{\prime}=\left(\mathrm{C}_{\mathrm{u}}{ }^{\prime}\left(\mathrm{C}_{\mathrm{u} 1} \Sigma \mathrm{C}_{\mathrm{u} 1}\right)^{-1} \mathrm{C}_{\mathrm{u}}\right)^{-1} \mathrm{C}_{\mathrm{u}}{ }^{\prime}\left(\mathrm{C}_{\mathrm{u} 1} \Sigma \mathrm{C}_{\mathrm{u} 1}\right)^{-1} \mathrm{C}_{\mathrm{u} 1} \xi, \text { and } \\
& \left(\epsilon_{\mathrm{A}}, \epsilon_{\mathrm{B}}\right)^{\prime}=\left(\mathrm{C}_{\mathrm{m}}{ }^{\prime}\left(\mathrm{C}_{\mathrm{m} 1} \Sigma \mathrm{C}_{\mathrm{m} 1}\right)^{-1} \mathrm{C}_{\mathrm{m}}\right)^{-1} \mathrm{C}_{\mathrm{m}}{ }^{\prime}\left(\mathrm{C}_{\mathrm{m} 1} \Sigma \mathrm{C}_{\mathrm{m} 1}\right)^{-1} \mathrm{C}_{\mathrm{m} 1} \xi .
\end{aligned}
$$


From our analysis of the stripped-down framework, $\operatorname{Var}\left(\epsilon_{\mathrm{A}} \mid \epsilon_{\mathrm{B}}\right) \leq \operatorname{Var}\left(\epsilon_{1} \mid \epsilon_{2}\right)$ implies that there exist constant $\alpha, \beta, \gamma$ and random noise $\mathrm{z}$ uncorrelated with $\left(\mathrm{x}_{\mathrm{A}}, \mathrm{x}_{\mathrm{B}}\right)$ such that for all $\mathrm{e}_{1}=\mathrm{e}_{\mathrm{A}}$,

$$
\left(\mathrm{x}_{1}, \mathrm{x}_{1}, \mathrm{x}_{2}, \mathrm{x}_{2}\right)=\left(\mathrm{x}_{\mathrm{A}}^{*}-\alpha \mathrm{x}_{\mathrm{B}}^{*}, \mathrm{x}_{\mathrm{A}}^{*}-\alpha \mathrm{x}_{\mathrm{B}}^{*}, \beta \mathrm{x}_{\mathrm{B}}^{*}, \beta \mathrm{x}_{\mathrm{B}}^{*}\right)+(\mathrm{z}, \mathrm{z}, \gamma, \gamma)
$$

in distribution. By Lemma 1, we can choose a random vector $\left(\mathrm{w}_{1}, \mathrm{w}_{2}, \mathrm{w}_{3}, \mathrm{w}_{4}\right)$ such that (i) $\operatorname{Var}\left(\mathrm{w}_{1}, \mathrm{w}_{2}, \mathrm{w}_{3}, \mathrm{w}_{4}\right)=\operatorname{Var}\left(\mathrm{u}_{1}, \mathrm{u}_{2}, \mathrm{u}_{3}, \mathrm{u}_{4}\right)=\operatorname{Var}\left(\mathrm{x}_{1 \mathrm{~A}}, \mathrm{x}_{1 \mathrm{~B}}, \mathrm{x}_{2 \mathrm{~A}}, \mathrm{x}_{2 \mathrm{~B}}\right)-\operatorname{Var}\left(\mathrm{x}_{1}, \mathrm{x}_{1}, \mathrm{x}_{2}, \mathrm{x}_{2}\right)$;

and

(ii) $\left(\mathrm{w}_{1}, \mathrm{w}_{2}, \mathrm{w}_{3}, \mathrm{w}_{4}\right)$ is independent of $\left(\mathrm{x}_{1}, \mathrm{x}_{2}\right),\left(\mathrm{x}_{\mathrm{A}}{ }^{*}, \mathrm{x}_{\mathrm{B}}{ }^{*}\right)$, and $\mathrm{z}$.

Then we obtain,

$$
\begin{aligned}
& \operatorname{Var}\left(\mathrm{x}_{1 \mathrm{~A}}, \mathrm{x}_{1 \mathrm{~B}}, \mathrm{x}_{2 \mathrm{~A}}, \mathrm{x}_{2 \mathrm{~B}}\right) \\
&= \operatorname{Var}\left(\mathrm{x}_{1}, \mathrm{x}_{1}, \mathrm{x}_{2}, \mathrm{x}_{2}\right)+\left[\operatorname{Var}\left(\mathrm{x}_{1 \mathrm{~A}}, \mathrm{x}_{1 \mathrm{~B}}, \mathrm{x}_{2 \mathrm{~A}}, \mathrm{x}_{2 \mathrm{~B}}\right)-\operatorname{Var}\left(\mathrm{x}_{1}, \mathrm{x}_{1}, \mathrm{x}_{2}, \mathrm{x}_{2}\right)\right] \\
&=\operatorname{Var}\left(\mathrm{x}_{\mathrm{A}}^{*}-\alpha \mathrm{x}_{\mathrm{B}}^{*}, \mathrm{x}_{\mathrm{A}}^{*}-\alpha \mathrm{x}_{\mathrm{B}}^{*}, \beta \mathrm{x}_{\mathrm{B}}^{*}, \beta \mathrm{x}_{\mathrm{B}}^{*}\right)+\operatorname{Var}(\mathrm{z}, \mathrm{z}, \gamma, \gamma)+\operatorname{Var}\left(\mathrm{w}_{1}, \mathrm{w}_{2}, \mathrm{w}_{3}, \mathrm{w}_{4}\right) \\
&=\operatorname{Var}\left(\mathrm{x}_{\mathrm{A}}^{*}-\alpha \mathrm{x}_{\mathrm{B}}^{*}+\mathrm{z}+\mathrm{w}_{1}, \mathrm{x}_{\mathrm{A}}^{*}-\alpha \mathrm{x}_{\mathrm{B}}^{*}+\mathrm{z}+\mathrm{w}_{2}, \beta \mathrm{x}_{\mathrm{B}}^{*}+\gamma+\mathrm{w}_{3}, \beta \mathrm{x}_{\mathrm{B}}{ }^{*}+\gamma+\mathrm{w}_{4}\right) .
\end{aligned}
$$

Furthermore,

$$
E\left(x_{1 \mathrm{~A}}, x_{1 B}, x_{2 A}, x_{2 B}\right)
$$

$=\mathrm{E}\left(\mathrm{x}_{1}, \mathrm{x}_{1}, \mathrm{x}_{2}, \mathrm{x}_{2}\right)$

$=\mathrm{E}\left(\mathrm{x}_{\mathrm{A}}{ }^{*}-\alpha \mathrm{x}_{\mathrm{B}}{ }^{*}+\mathrm{z}+\mathrm{w}_{1}, \mathrm{x}_{\mathrm{A}}{ }^{*}-\alpha \mathrm{x}_{\mathrm{B}}{ }^{*}+\mathrm{z}+\mathrm{w}_{2}, \beta \mathrm{x}_{\mathrm{B}}{ }^{*}+\gamma+\mathrm{w}_{3}, \beta \mathrm{x}_{\mathrm{B}}{ }^{*}+\gamma+\mathrm{w}_{4}\right)$.

Therefore we obtain

$$
\left(\mathrm{x}_{1 \mathrm{~A}}, \mathrm{x}_{1 \mathrm{~B}}, \mathrm{x}_{2 \mathrm{~A}}, \mathrm{x}_{2 \mathrm{~B}}\right)=\left(\mathrm{x}_{\mathrm{A}}{ }^{*}-\alpha \mathrm{x}_{\mathrm{B}}{ }^{*}+\mathrm{Z}+\mathrm{w}_{1}, \mathrm{x}_{\mathrm{A}}{ }^{*}-\alpha \mathrm{x}_{\mathrm{B}}{ }^{*}+\mathrm{Z}+\mathrm{w}_{2}, \beta \mathrm{x}_{\mathrm{B}}{ }^{*}+\gamma+\mathrm{w}_{3}, \beta \mathrm{x}_{\mathrm{B}}{ }^{*}+\gamma+\mathrm{w}_{4}\right)
$$

in distribution.

Finally, we define

$$
\mathrm{t}_{\mathrm{A}}\left(\mathrm{x}_{1 \mathrm{~A}}{ }^{*}, \mathrm{x}_{2 \mathrm{~A}}{ }^{*}, \mathrm{x}_{1 \mathrm{~B}}{ }^{*}, \mathrm{x}_{2 \mathrm{~B}}{ }^{*}\right)=\mathrm{t}_{1}\left(\mathrm{x}_{\mathrm{A}}{ }^{*}-\alpha \mathrm{x}_{\mathrm{B}}{ }^{*}+\mathrm{z}+\mathrm{w}_{1}, \mathrm{x}_{\mathrm{A}}{ }^{*}-\alpha \mathrm{x}_{\mathrm{B}}{ }^{*}+\mathrm{z}+\mathrm{w}_{2}, \beta \mathrm{x}_{\mathrm{B}}{ }^{*}+\gamma+\mathrm{w}_{3}, \beta \mathrm{x}_{\mathrm{B}}{ }^{*}+\gamma+\mathrm{w}_{4}\right),
$$

which is the same as $t_{1}\left(x_{1 A}, x_{1 B}, x_{2 A}, x_{2 B}\right)$ in distribution. Q.E.D.

\section{Proof of Proposition 3: Let}

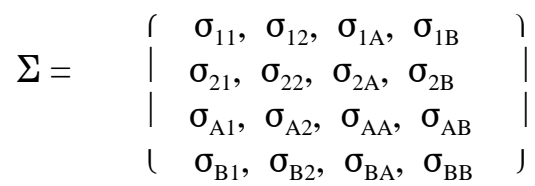


and

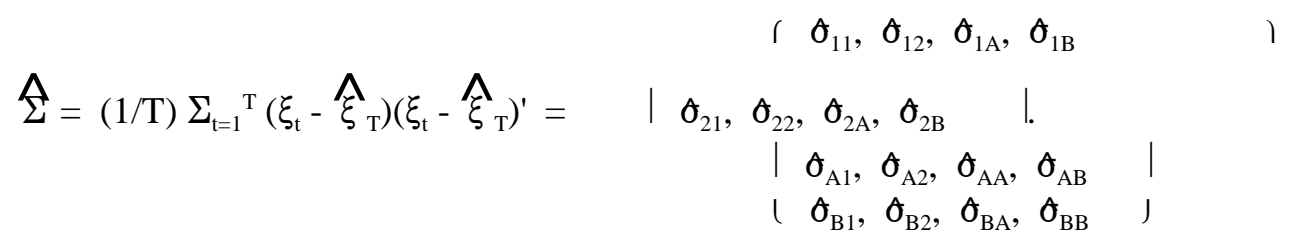

Vectorizing $\Sigma$ and $\hat{\Sigma}$, we have (by Theorem 3.4.4 of Anderson, 1984):

$$
\mathrm{T}^{1 / 2}(\operatorname{vec}(\hat{\Sigma})-\operatorname{vec}(\Sigma))-->\mathrm{N}(0, \mathrm{~B}(\Sigma))
$$

as $\mathrm{T}-->\infty$, where $\mathrm{B}(\Sigma)$ is a $16 \times 16$ matrix with elements $\mathrm{b}_{\mathrm{ij}, \mathrm{kl}}=\sigma_{\mathrm{ik}} \sigma_{\mathrm{jl}}+\sigma_{\mathrm{il}} \sigma_{\mathrm{jk}}, \mathrm{i}, \mathrm{j}, \mathrm{k}, \mathrm{l}=1,2, \mathrm{~A}, \mathrm{~B}$.

From the proof of Lemma 1, we know that

$$
\begin{aligned}
& \left(\epsilon_{1}, \epsilon_{2}\right)^{\prime}=\left(\mathrm{C}_{\mathrm{u}}^{\prime}\left(\mathrm{C}_{\mathrm{u} 1} \Sigma \mathrm{C}_{\mathrm{u} 1}\right)^{-1} \mathrm{C}_{\mathrm{u}}\right)^{-1} \mathrm{C}_{\mathrm{u}}\left(\mathrm{C}_{\mathrm{u} 1} \Sigma \mathrm{C}_{\mathrm{u} 1}\right)^{-1} \mathrm{C}_{\mathrm{u} 1} \xi^{\prime} \text { and } \\
& \left(\epsilon_{\mathrm{A}}, \epsilon_{\mathrm{B}}\right)^{\prime}=\left(\mathrm{C}_{\mathrm{m}}{ }^{\prime}\left(\mathrm{C}_{\mathrm{m} 1} \Sigma \mathrm{C}_{\mathrm{m} 1}\right)^{-1} \mathrm{C}_{\mathrm{m}}\right)^{-1} \mathrm{C}_{\mathrm{m}}{ }^{\prime}\left(\mathrm{C}_{\mathrm{m} 1} \Sigma \mathrm{C}_{\mathrm{m} 1}\right)^{-1} \mathrm{C}_{\mathrm{m} 1} \xi^{\prime} .
\end{aligned}
$$

Therefore,

$$
\Phi(\Sigma)=\left(\begin{array}{l}
\Phi_{\mathrm{u}}(\Sigma) \\
\Phi_{\mathrm{m}}(\Sigma)
\end{array}\right)=\left(\begin{array}{l}
\left(\mathrm{C}_{\mathrm{u}}^{\prime}\left(\mathrm{C}_{\mathrm{u} 1} \Sigma \mathrm{C}_{\mathrm{u} 1}^{\prime}\right)^{-1} \mathrm{C}_{\mathrm{u}}\right)^{-1} \mathrm{C}_{\mathrm{u}}^{\prime}\left(\mathrm{C}_{\mathrm{u} 1} \Sigma \mathrm{C}_{\mathrm{u} 1}\right)^{-1} \mathrm{C}_{\mathrm{u} 1} \\
\left(\left(\mathrm{C}_{\mathrm{m}}^{\prime}\left(\mathrm{C}_{\mathrm{m} 1} \Sigma \mathrm{C}_{\mathrm{m} 1}\right)^{-1} \mathrm{C}_{\mathrm{m}}\right)^{-1} \mathrm{C}_{\mathrm{m}}^{\prime}\left(\mathrm{C}_{\mathrm{m} 1} \Sigma \mathrm{C}_{\mathrm{m} 1}\right)^{-1} \mathrm{C}_{\mathrm{m} 1}\right.
\end{array}\right)
$$

Using matrix differential calculus (Magnus and Neudecker, 1988, pp.27-31, 46-48, 94-97, 147-149, and 173-184), we obtain

(A1) $\mathrm{d} \Omega=\mathrm{d}\left(\Phi(\Sigma) \Sigma \Phi(\Sigma)^{\prime}\right)=\mathrm{d} \Phi(\Sigma) \Sigma \Phi(\Sigma)^{\prime}+\Phi(\Sigma) \mathrm{d} \Sigma \Phi(\Sigma)^{\prime}+\Phi(\Sigma) \Sigma \mathrm{d} \Phi(\Sigma)^{\prime}$.

Using matrix differential calculus again, for $\mathrm{i}=\mathrm{u}, \mathrm{m}$, we obtain:

$$
\begin{aligned}
\mathrm{d} \Phi_{\mathrm{i}}(\Sigma)^{\prime} & =\mathrm{d}\left\{\mathrm{C}_{\mathrm{i} 1}{ }^{\prime}\left(\mathrm{C}_{\mathrm{i} 1} \Sigma \mathrm{C}_{\mathrm{i} 1}\right)^{-1} \mathrm{C}_{\mathrm{i}}\left(\mathrm{C}_{\mathrm{i}}^{\prime}\left(\mathrm{C}_{\mathrm{i} 1} \Sigma \mathrm{C}_{\mathrm{i} 1}\right)^{-1} \mathrm{C}_{\mathrm{i}}\right)^{-1}\right\} \\
& =-\mathrm{C}_{\mathrm{i} 1}\left(\mathrm{C}_{\mathrm{i} 1} \Sigma \mathrm{C}_{\mathrm{i} 1}\right)^{-1} \mathrm{C}_{\mathrm{i} 1}(\mathrm{~d} \Sigma) \Phi_{\mathrm{i}}(\Sigma)^{\prime}+\mathrm{C}_{\mathrm{i} 1}\left(\mathrm{C}_{\mathrm{i} 1} \Sigma \mathrm{C}_{\mathrm{i} 1}\right)^{-1} \mathrm{C}_{\mathrm{i}} \Phi_{\mathrm{i}}(\Sigma)(\mathrm{d} \Sigma) \Phi_{\mathrm{i}}(\Sigma)^{\prime} .
\end{aligned}
$$

Thus,

$$
\begin{aligned}
\mathrm{d} \Phi(\Sigma)^{\prime}=\left[-\mathrm{C}_{\mathrm{u} 1}{ }^{\prime}\left(\mathrm{C}_{\mathrm{u} 1} \Sigma \mathrm{C}_{\mathrm{u} 1}\right)^{-1} \mathrm{C}_{\mathrm{u} 1}(\mathrm{~d} \Sigma) \Phi_{\mathrm{u}}(\Sigma)^{\prime}+\mathrm{C}_{\mathrm{u} 1}\left(\mathrm{C}_{\mathrm{u} 1} \Sigma \mathrm{C}_{\mathrm{u} 1}\right)^{-1} \mathrm{C}_{\mathrm{u}} \Phi_{\mathrm{u}}(\Sigma)(\mathrm{d} \Sigma) \Phi_{\mathrm{u}}(\Sigma)^{\prime}\right. \\
\\
\left.-\mathrm{C}_{\mathrm{m} 1}\left(\mathrm{C}_{\mathrm{m} 1} \Sigma \mathrm{C}_{\mathrm{m} 1}\right)^{-1} \mathrm{C}_{\mathrm{m} 1}(\mathrm{~d} \Sigma) \Phi_{\mathrm{m}}(\Sigma)^{\prime}+\mathrm{C}_{\mathrm{m} 1}\left(\mathrm{C}_{\mathrm{m} 1} \Sigma \mathrm{C}_{\mathrm{m} 1}\right)^{-1} \mathrm{C}_{\mathrm{m}} \Phi_{\mathrm{m}}(\Sigma)(\mathrm{d} \Sigma) \Phi_{\mathrm{m}}(\Sigma)^{\prime}\right]
\end{aligned}
$$

and

$$
\begin{gathered}
\operatorname{vec}\left(\mathrm{d} \Phi(\Sigma)^{\prime}\right)=\operatorname{vec}\left\{\left[-\left(\Phi_{\mathrm{u}}(\Sigma) \otimes \mathrm{C}_{\mathrm{u} 1}{ }^{\prime}\left(\mathrm{C}_{\mathrm{u} 1} \Sigma \mathrm{C}_{\mathrm{u} 1}\right)^{-1} \mathrm{C}_{\mathrm{u} 1}\right)+\left(\Phi_{\mathrm{u}}(\Sigma) \otimes \mathrm{C}_{\mathrm{u} 1}{ }^{\prime}\left(\mathrm{C}_{\mathrm{u} 1} \Sigma \mathrm{C}_{\mathrm{u} 1}\right)^{-1} \mathrm{C}_{\mathrm{u}} \Phi_{\mathrm{u}}(\Sigma)\right] \mathrm{d}(\operatorname{vec}(\Sigma))\right.\right. \\
{\left[-\left(\Phi_{\mathrm{m}}(\Sigma) \otimes \mathrm{C}_{\mathrm{m} 1}\left(\mathrm{C}_{\mathrm{m} 1} \Sigma \mathrm{C}_{\mathrm{m} 1}\right)^{\prime-1} \mathrm{C}_{\mathrm{m} 1}\right)+\left(\Phi_{\mathrm{m}}(\Sigma) \otimes \mathrm{C}_{\mathrm{m} 1}{ }^{\prime}\left(\mathrm{C}_{\mathrm{m} 1} \Sigma \mathrm{C}_{\mathrm{m} 1}\right)^{-1} \mathrm{C}_{\mathrm{m}} \Phi_{\mathrm{m}}(\Sigma)\right] \mathrm{d}(\operatorname{vec}(\Sigma))\right\}}
\end{gathered}
$$




$$
\left.=\begin{array}{ll}
\left(-\Phi_{\mathrm{u}}(\Sigma) \otimes \mathrm{C}_{\mathrm{u} 1}{ }^{\prime}\left(\mathrm{C}_{\mathrm{u} 1} \Sigma \mathrm{C}_{\mathrm{u} 1}\right)^{-1} \mathrm{C}_{\mathrm{u} 1}+\Phi_{\mathrm{u}}(\Sigma) \otimes \mathrm{C}_{\mathrm{u} 1}{ }^{\prime}\left(\mathrm{C}_{\mathrm{u} 1} \Sigma \mathrm{C}_{\mathrm{u} 1}\right)^{-1} \mathrm{C}_{\mathrm{u}} \Phi_{\mathrm{u}}(\Sigma) \quad\right) \mathrm{d}(\mathrm{vec}(\Sigma)) . \\
\left(-\Phi_{\mathrm{m}}(\Sigma) \otimes \mathrm{C}_{\mathrm{m} 1}\left(\mathrm{C}_{\mathrm{m} 1} \Sigma \mathrm{C}_{\mathrm{m} 1}\right)^{-1} \mathrm{C}_{\mathrm{m} 1}+\Phi_{\mathrm{m}}(\Sigma) \otimes \mathrm{C}_{\mathrm{m} 1}\left(\mathrm{C}_{\mathrm{m} 1} \Sigma \mathrm{C}_{\mathrm{m} 1}\right)^{-1} \mathrm{C}_{\mathrm{m}} \Phi_{\mathrm{m}}(\Sigma)\right.
\end{array}\right)
$$

where $\otimes$ is the Kronecker product. ${ }^{15}$

Define

$$
\begin{array}{r}
\mathrm{V}(\Sigma)=\left(-\Phi_{\mathrm{u}}(\Sigma) \otimes \mathrm{C}_{\mathrm{u} 1}\left(\mathrm{C}_{\mathrm{u} 1} \Sigma \mathrm{C}_{\mathrm{u} 1}\right)^{-1} \mathrm{C}_{\mathrm{u} 1}+\Phi_{\mathrm{u}}(\Sigma) \otimes \mathrm{C}_{\mathrm{u} 1}\left(\mathrm{C}_{\mathrm{u} 1} \Sigma \mathrm{C}_{\mathrm{u} 1}\right)^{-1} \mathrm{C}_{\mathrm{u}} \Phi_{\mathrm{u}}(\Sigma)\right. \\
\left(-\Phi_{\mathrm{m}}(\Sigma) \otimes \mathrm{C}_{\mathrm{m} 1}\left(\mathrm{C}_{\mathrm{m} 1} \Sigma \mathrm{C}_{\mathrm{m} 1}\right)^{-1} \mathrm{C}_{\mathrm{m} 1}+\Phi_{\mathrm{m}}(\Sigma) \otimes \mathrm{C}_{\mathrm{m} 1}\left(\mathrm{C}_{\mathrm{m} 1} \Sigma \mathrm{C}_{\mathrm{m} 1}\right)^{-1} \mathrm{C}_{\mathrm{m}} \Phi_{\mathrm{m}}(\Sigma)\right)
\end{array}
$$

Then

$$
\begin{aligned}
& \operatorname{vec}\left(\mathrm{d} \Phi(\Sigma)^{\prime}\right)=\mathrm{V}(\Sigma) \mathrm{d}(\operatorname{vec}(\Sigma)), \text { and } \\
& \operatorname{vec}(\mathrm{d} \Phi(\Sigma))=\operatorname{vec}\left(\mathrm{d} \Phi(\Sigma)^{\prime}\right)^{\prime}=\mathrm{K} \operatorname{vec}\left(\mathrm{d} \Phi(\Sigma)^{\prime}\right) \\
& =\mathrm{K} \mathrm{V}(\Sigma) \mathrm{d}(\operatorname{vec}(\Sigma)),
\end{aligned}
$$

where $\mathrm{K}$ is the commutation matrix. ${ }^{16}$

Therefore, using (A1), we get

$\operatorname{dvec}(\Omega)=\operatorname{vec}(d \Omega)$

$=(\Phi(\Sigma) \Sigma \otimes \mathrm{I}) \operatorname{vec}(\mathrm{d} \Phi(\Sigma))+(\Phi(\Sigma) \otimes \Phi(\Sigma)) \operatorname{vec}(\mathrm{d} \Sigma)+(\mathrm{I} \otimes \Phi(\Sigma) \Sigma) \operatorname{vec}\left(\mathrm{d} \Phi(\Sigma)^{\prime}\right)$

$=(\Phi(\Sigma) \Sigma \otimes \mathrm{I}) \mathrm{KV}(\Sigma) \mathrm{d}(\operatorname{vec}(\Sigma))+(\Phi(\Sigma) \otimes \Phi(\Sigma)) \operatorname{vec}(\mathrm{d} \Sigma)+(\mathrm{I} \otimes \Phi(\Sigma) \Sigma) \mathrm{V}(\Sigma) \mathrm{d}(\operatorname{vec}(\Sigma))$

$=[\Phi(\Sigma) \otimes \Phi(\Sigma)+(\mathrm{K}+\mathrm{I})(\mathrm{I} \otimes \Phi(\Sigma) \Sigma) \mathrm{V}(\Sigma)] \mathrm{d}(\operatorname{vec}(\Sigma))$,

where I is the identity matrix.

Hence,

$\mathrm{dvec}(\Omega) / \mathrm{d}(\operatorname{vec}(\Sigma))^{\prime}=\Phi(\Sigma) \otimes \Phi(\Sigma)+(\mathrm{K}+\mathrm{I})(\mathrm{I} \otimes \Phi(\Sigma) \Sigma) \mathrm{V}(\Sigma)$.

Therefore, we have, as $\mathrm{T}-->\infty$,

$$
\mathrm{T}^{1 / 2}(\mathrm{~h}(\Omega(\widehat{\Sigma}))-\mathrm{h}(\Omega(\Sigma)))-->\mathrm{N}(0, \mathrm{D}(\Sigma))
$$

\footnotetext{
${ }^{15}$ Let $\mathrm{U}$ be an $m \times n$ matrix and $\mathrm{W}$ be an $p \times q$ matrix. The Kronecker product of $\mathrm{U}$ and $\mathrm{W}(\mathrm{U} \otimes \mathrm{W})$ is defined by the following $m p \times n q$ matrix

$$
\left\{\begin{array}{lll}
u_{11} W \ldots & u_{1 n} W \\
u_{m 1} W & \ldots & u_{m n} W
\end{array}\right)
$$

(Magnus and Neudecker, 1988, p.27).

${ }^{16}$ Let A be an $m \times n$ matrix. The commutation matrix $\mathrm{K}$ is such that $\mathrm{K} \operatorname{vec} \mathrm{A}=\operatorname{vec} \mathrm{A}^{\prime}$

(Magnus and Neudecker, 1988, pp.46-48).
} 
with $\mathrm{D}(\Sigma)=\left(\mathrm{dh}(\Omega) / \mathrm{d}(\operatorname{vec}(\Omega))^{\prime}\right)\left(\operatorname{dvec}(\Omega) / \mathrm{d}(\operatorname{vec}(\Sigma))^{\prime}\right) \mathrm{B}(\Sigma)\left(\operatorname{dvec}(\Omega) / \mathrm{d}(\operatorname{vec}(\Sigma))^{\prime}\right)^{\prime}\left(\operatorname{dh}(\Sigma) / \mathrm{d}(\operatorname{vec}(\Sigma))^{\prime}\right)^{\prime}$,

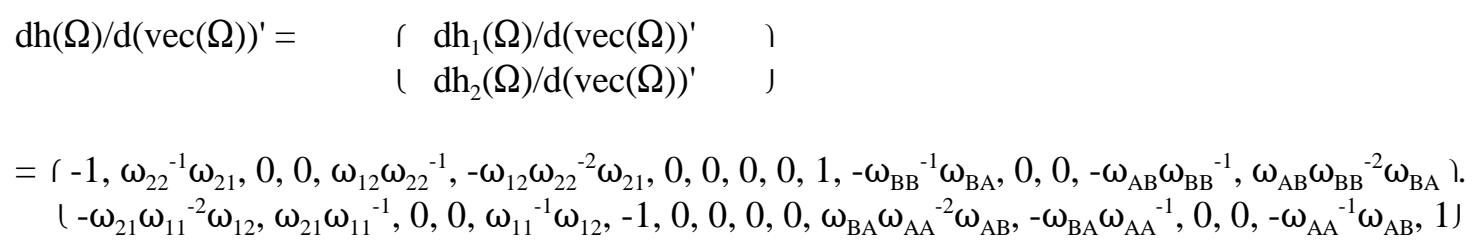

We now consider the problem

$$
\mathrm{h}(\Omega(\widehat{\Sigma}))=\mathrm{h}(\Omega(\Sigma))+\mathrm{T}^{-1 / 2} \mathrm{v}
$$

where $\mathrm{v} \sim \mathrm{N}(0, \mathrm{D}(\Sigma))$. The proof is completed by using Wolak (1987). Q.E.D. 


\section{$\underline{\text { References }}$}

Aghion, Philippe and Jean Tirole, "Some Implications of Growth for Organizational Form and Ownership Structure," European Economic Review, 1995.

Anderson, T.W., An Introduction to Multivariate Statistical Analysis (2nd edition), New York: Wiley, 1984.

Aoki, Masahiko, "Horizontal vs. Vertical Information Structure of the Firm," American Economic Review, 76(5): 971-83, December 1986.

Arrow, Kenneth, The Limits of Organization, New York: Norton, 1974.

Bartke, Wolfgang, Biographical Dictionary and Analysis of China's Party Leadership, 1922-1988, NY: K.G. Saur, 1990.

Chandler, Alfred Jr., Strategy and Structure, New York: Doubleday \& Company, Inc., 1962.

Cremer, Jacques, "A Partial Theory of the Optimal Organization of Bureaucracy," Bell Journal of Economics, 11, 683-693, 1980.

Earle, John, and R. Ross, "Ownership Transformation, Economic Behavior, and Political Attitudes in Russia," mimeo, 1996.

Gregory, Paul R., and Robert C. Stuart, Soviet Economic Structure and Performance, New York: Harper \& Row, Publishers, 1981.

Holmstrom, Bengt, "Moral Hazard in Teams," Bell Journal of Economics, 13:324-340, 1982.

Holmstrom, Bengt and Paul Milgrom, "Multi-task Principal-Agent Analysis: Incentive Contracts, Asset Ownership and Job Design," Journal of Law, Economics, and Organization, 7:24-52, 1991.

Holmstrom, Bengt and Paul Milgrom, "The Firm as an Incentive System," American Economic Review, 84:972-991, 1994.

Kornai, Janos, The Socialist System, Princeton University Press, 1992.

Lazear, Edward P. and Sherwin Rosen, "Rank-Order Tournaments as Optimum Labor Contracts," Journal of Political Economy, 89(5), October, 1981.

Magnus, Jan R., and Heinz Neudecker, Matrix Differential Calculus with Applications in Statistics and Econometrics, John Wiley \& Sons, 1988.

Milgrom, Paul, and John Roberts, Economics, Organization, and Management, Prentice Hall, 1992.

Mirrlees, James A., "Notes on Welfare Economics, Information and Uncertainty," in M. Balch, D. McFadden and S. Wu (eds.), Essays in Economic Behavior under Uncertainty, pp.243-58, 1974. 
Nalebuff, Barry, and Joseph Stiglitz, "Prizes and Incentives: Towards a General Theory of Compensation and Competition," Bell Journal of Economics, 1983.

Qian, Yingyi, Gerard Roland, and Chenggang Xu, "Coordinating Changes in M-form and U-form Organizations," mimeo, Stanford University, ECARE, and LSE, 1997.

Qian, Yingyi, and Chenggang Xu, "Why China's Economic Reform Differ: The M-form Hierarchy and Entry/Expansion of the Non-state Sector," Economics of Transition, 1(2), pp.135-170, June, 1993.

Saich, Tony, "The Fourteenth Party Congress: A Program for Authoritarian Rule," China Quarterly, 132:1136-1160, December, 1992.

Shleifer, Andrei, "A Theory of Yardstick Competition," RAND Journal of Economics, 16(3):319-27, Autumn, 1985.

State Statistical Bureau, Quanguo gesheng, zizhiqu, zhixiashi tongji ziliao huibian, 1949-1989 (Collections of Historical Statistical Materials of All Provinces, Autonomous Regions, and Provincial Level Municipalities, 1949-1989), Beijing: National Statistics Press, 1990.

Whiting, Susan, The Micro-Foundations of Institutional Change in Reform China: Property Rights and Revenue Extraction in the Rural Industrial Sector, Ph.D. dissertation, University of Michigan, 1995.

Williamson, Oliver, Markets and Hierarchies, New York: Free Press, 1975.

Wolak, Frank, "An Exact Test for Multiple Inequality and Equality Constraints in the Linear Regression Model," Journal of the American Statistical Association, 82(399), September 1987. 